\title{
Stimulatory effect of Echinacea purpurea extract on the trafficking activity of mouse dendritic cells: revealed by genomic and proteomic analyses
}

\author{
Shu-Yi Yin ${ }^{1,3,4}$, Wen-Hsin Wang ${ }^{1}$, Pei-Hsueh Wang ${ }^{1}$, Kandan Aravindaram ${ }^{1}$, Pei-Ing Hwang ${ }^{2}$, Han-Ming Wu ${ }^{5}$,
} Ning-Sun Yang ${ }^{1,3,4^{*}}$

\begin{abstract}
Background: Several Echinacea species have been used as nutraceuticals or botanical drugs for "immunostimulation", but scientific evidence supporting their therapeutic use is still controversial. In this study, a phytocompound mixture extracted from the butanol fraction (BF) of a stem and leaf $(\mathrm{S}+\mathrm{L}$ ) extract of E. purpurea $([\mathrm{BF} / \mathrm{S}+\mathrm{L} / \mathrm{Ep}])$ containing stringently defined bioactive phytocompounds was obtained using standardized and published procedures. The transcriptomic and proteomic effects of this phytoextract on mouse bone marrowderived dendritic cells (BMDCs) were analyzed using primary cultures.
\end{abstract}

Results: Treatment of BMDCs with $[\mathrm{BF} / \mathrm{S}+\mathrm{L} / \mathrm{Ep}]$ did not significantly influence the phenotypic maturation activity of dendritic cells (DCs). Affymetrix DNA microarray and bioinformatics analyses of genes differentially expressed in DCs treated with $[\mathrm{BF} / \mathrm{S}+\mathrm{L} / \mathrm{Ep}]$ for 4 or $12 \mathrm{~h}$ revealed that the majority of responsive genes were related to cell adhesion or motility (Cdh10, Itga6, Cdh1, Gja1 and Mmp8), or were chemokines (CxCl2, CxCl7) or signaling molecules (Nrxn1, Pkce and Acss1). TRANSPATH database analyses of gene expression and related signaling pathways in treated-DCs predicted the JNK, PP2C- $\alpha, A K T$, ERK1/2 or MAPKAPK pathways as the putative targets of [BF/S+L/Ep]. In parallel, proteomic analysis showed that the expressions of metabolic-, cytoskeleton- or NF- $\kappa$ B signaling-related proteins were regulated by treatment with $[\mathrm{BF} / \mathrm{S}+\mathrm{L} / \mathrm{Ep}]$. In vitro flow cytometry analysis of chemotaxis-related receptors and in vivo cell trafficking assay further showed that DCs treated with $[\mathrm{BF} / \mathrm{S}+\mathrm{L} / \mathrm{Ep}]$ were able to migrate more effectively to peripheral lymph node and spleen tissues than DCs treated as control groups.

Conclusion: Results from this study suggest that $[\mathrm{BF} / \mathrm{S}+\mathrm{L} / \mathrm{Ep}]$ modulates $\mathrm{DC}$ mobility and related cellular physiology in the mouse immune system. Moreover, the signaling networks and molecules highlighted here are potential targets for nutritional or clinical application of Echinacea or other candidate medicinal plants.

\section{Background}

Dendritic cells (DCs) participate in a wide spectrum of immune cell functions including antigen-presentation, phagocytic activity and T cell-mediated immunities [1]. Currently, a number of experimental approaches are being evaluated to develop DC-based immunotherapy and gene-based tumor vaccine strategies to elicit specific immunities against specific cancers (e.g., prostate cancer) or infectious diseases [2-8]. DCs can capture and take up antigens present in peripheral tissue and transport them

\footnotetext{
* Correspondence: nsyang@gate.sinica.edu.tw

${ }^{1}$ Agricultural Biotechnology Research Center, Academia Sinica, Taipei, Taiwan Full list of author information is available at the end of the article
}

\footnotetext{
Full tist of author information is avalable at the end of the article
}

to primary and secondary lymphoid tissue for presentation to T cells [4]. Therefore, extensive research regarding cell migration, homing, and the cellular fate of DCs in various tissue systems is considered a critical issue. Research on mouse bone marrow-derived dendritic cells (BMDCs) has shown the importance of using experimental models for research into DC-based therapeutics [5-8]. We recently reported the effect and possible application of Echinacea purpurea (Ep) phytocompounds as immune-modifiers for human DCs using functional genomic and proteomic approaches $[9,10]$. Here, we extended our study to the mouse DC system, and investigated the effects of the chemically defined Ep phytoextracts $(\mathrm{BF} / \mathrm{S}+\mathrm{L} / \mathrm{Ep})$ on immunomodulatory activity and

(c) 2010 Yin et al; licensee BioMed Central Ltd. This is an Open Access article distributed under the terms of the Creative Commons Attribution License (http://creativecommons.org/licenses/by/2.0), which permits unrestricted use, distribution, and reproduction in 
cell migration/trafficking activities of DCs under ex vivo and in vivo conditions.

Since the 1990s, the use of Echinacea spp. as a medicinal plant or food supplement has gained popularity in the USA and Europe [11,12], and is now even recognized in Asia (e.g., China). The possible effects of Echinacea spp. extracts on in vitro activation of macrophages, natural killer (NK) cells, and other immune cell types [13-15], and on stimulating the expression of cytokines such as tumor necrosis factor-alpha (TNF- $\alpha$ ), interferon, interleukin-1 and interleukin-6 [16] have all been reported. In vivo studies showed that treatment with Echinacea extracts can increase white blood cell populations in the circulation system [17], and enhance phagocytosis [18]. E. purpurea extracts have been evaluated in clinical trials for efficiency against the common cold, but the controversial results are continuously disputed $[9,10,12,19,20]$. To systemically assess the immunomodulatory effects on mouse DCs in vivo, we employed a chemically defined Echinacea purpurea extract, termed $[\mathrm{BF} / \mathrm{S}+\mathrm{L} / \mathrm{Ep}]$, containing hypoxanthine, chlorogenic acid, caffeic acid, cichoric acid, quercetin-3-O-rhamnosyl$(1 \rightarrow 6)$-galactoside, kaempferol-3-O-rhamnosyl-(1 $\rightarrow 6)$ galactoside and rutin [10].

Profiling of specific and global gene expression patterns by DNA microarray analysis coupled with proteomic analysis provides a useful approach for the investigation of complex biological phenomena $[21,22]$ as we have previously shown for immune cell systems $[9,10]$. In this study, we used a network knowledge-based approach to analyze genome-wide transcriptome activity in vitro and in vivo, for correlation to specific proteome activities and special functional phenotypes in mouse immature BMDCs, in response to treatment with [BF/S+L/Ep]. Our findings suggest that $[\mathrm{BF} / \mathrm{S}+\mathrm{L} / \mathrm{Ep}]$ was able to modulate cell adhesion-, cell mobility-, cytokine- and NF- $\kappa \mathrm{B}$ signaling-related activities in primary cultures of mouse DCs. In vivo trafficking experiments using ex vivo-treated DCs demonstrated that $[\mathrm{BF} / \mathrm{S}+\mathrm{L} / \mathrm{Ep}]$ could enhance the mobility of DCs to target specific lymphoid organs in test mouse. Moreover, bioinformatics studies allowed us to predict several candidate target molecules for the future translational studies of this or other phytocompound mixtures. The significance of our findings and potential application to future studies of human DCs are discussed.

\section{Results}

1. Expression of DC markers in response to treatment with $[B F / S+L / E p]$

Initially, we set out to examine whether $[\mathrm{BF} / \mathrm{S}+\mathrm{L} / \mathrm{Ep}]$ could influence the maturation activity of BMDCs. Mouse bone marrow cells were isolated and cultured for 9 days in RPMI-1640 supplemented with $200 \mathrm{U} / \mathrm{mL}$ GMCSF. DCs cultured in the presence of GM-CSF showed the functional and phenotypic characteristics of the immature stage and could be further differentiated in vitro into mature DCs. LPS, at $1 \mu \mathrm{g} / \mathrm{mL}$, was then used to induce maturation of DCs. Some test cells were analyzed for the effect of $[B F / S+L / E p]$ for $24 \mathrm{~h}$. Since concentrations of $[\mathrm{BF} / \mathrm{S}+\mathrm{L} / \mathrm{Ep}]$ greater than $100 \mu \mathrm{g} / \mathrm{mL}$ were slightly cytotoxic to test dendritic cells (evaluated using MTT cell viability assays, data not shown), [BF/S+L/Ep] was used at a concentration of $75 \mu \mathrm{g} / \mathrm{mL}$, where no cytotoxicity was detectable. As seen in Figure 1, sharp peak signals were obtained in flow cytometry analyses, demonstrating that high quality DCs were routinely obtained. Flow cytometry analysis on the expression of CD40, CD80, CD86, MHC class II and CD11c on BMDCs showed that the control group expressed lower levels of co-stimulatory and activation molecules than the LPStreated groups. There was no significant difference between the DMSO-treated and $[\mathrm{BF} / \mathrm{S}+\mathrm{L} / \mathrm{Ep}]$-treated groups (Figure 1). Compared with the LPS group, BMDCs co-treated with $75 \mu \mathrm{g} / \mathrm{ml}[\mathrm{BF} / \mathrm{S}+\mathrm{L} / \mathrm{Ep}]$ and $1 \mu \mathrm{g} /$ $\mathrm{mL}$ LPS only showed a weak inhibition of CD40 at $24 \mathrm{~h}$ post-LPS treatment, whereas expression of CD40, CD86, MHC class II and CD11c were not significantly affected. These data indicate that $[\mathrm{BF} / \mathrm{S}+\mathrm{L} / \mathrm{Ep}]$ did not have a significant effect on the phenotypic maturation of mouse BMDCs.

\section{Differential gene expression in immature BMDCs as a response to treatment with $[B F / S+L / E p]$}

We next investigated the expression of specific genes related to the cellular biochemistry and physiology of immature DCs. Affymetrix DNA microarray analyses showed that, although the gene expression of the cell surface markers tested above were not affected, a series of other genes related to DC activities were affected by $75 \mu \mathrm{g} / \mathrm{ml}[\mathrm{BF} / \mathrm{S}+\mathrm{L} / \mathrm{Ep}]$. Initial experimental setups using biological sample replicates showed that our test cell culture systems and experimental protocols, e.g., RNA preparation, were highly reproducible and consistent, e.g., Pearson's Correlation values for test biological sample replicates were between 0.993 and 0.996 (Figure 2). All genes identified from the raw data of our Affymetrix gene chip analyses were subjected to a gene filtering proctocol, using established statistics software (Spotfire), to select and identify candidate differentially expressed genes for further studies. We chose genes that scored positive in at least 4 different chips and that had a coefficient of variation (CV) of over 0.4. A total of 907 and 1256 genes had changed expression significantly by $4 \mathrm{~h}$ and by $12 \mathrm{~h}$ post-treatment with $[\mathrm{BF} / \mathrm{S}+\mathrm{L} / \mathrm{Ep}]$, respectively. Among these, 172 and 264 genes respectively were identified as immune-related genes (Table 1). For up-regulated or down-regulated genes, only those genes that showed at least a 2-fold change in RNA transcript 


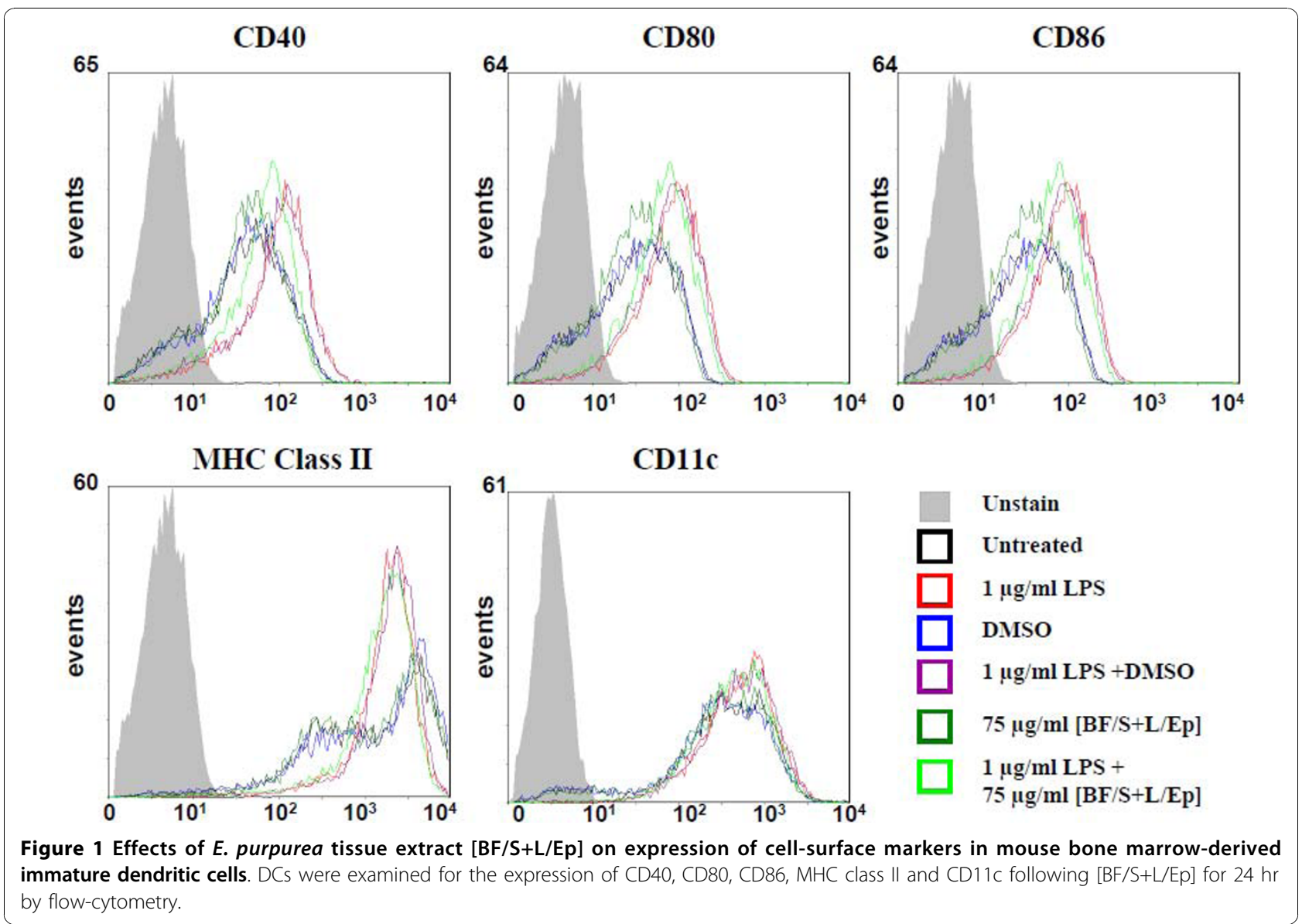

level in two independent experiments were considered for further analysis. Differences in expression level were calculated by dividing the signal intensity values of genes from $[\mathrm{BF} / \mathrm{S}+\mathrm{L} / \mathrm{Ep}]$-treated cells by the intensity values of genes from the vehicle-treated (control) cells. Overall, similar numbers of genes were up-regulated and down-regulated after treatment with $[\mathrm{BF} / \mathrm{S}+\mathrm{L} / \mathrm{Ep}]$ (Table 1). The expression of 29 genes more than doubled in $[\mathrm{BF} / \mathrm{S}+\mathrm{L} / \mathrm{Ep}]$-treated DCs, compared to vehicle control, at $4 \mathrm{~h}$ post-treatment, and a group of 31 genes were up-regulated (i.e., $\geq 2$-fold change) at $12 \mathrm{~h}$ post-treatment. In contrast, 26 and 35 genes were down-regulated (expression more than halved) in $[\mathrm{BF} /$ $\mathrm{S}+\mathrm{L} / \mathrm{Ep}]$-treated DCs at $4 \mathrm{~h}$ and $12 \mathrm{~h}$ post-treatment, respectively (Table 1 ). It is important to note that two different sets of 51 non-immune related genes were highly affected at $4 \mathrm{~h}$ and $12 \mathrm{~h}$ time points (Table 1 ). The relative changes in gene expression levels in $[\mathrm{BF} /$ $\mathrm{S}+\mathrm{L} / \mathrm{Ep}$ ]-treated DCs are shown in Table 2 and Table 3 for $4 \mathrm{~h}$ and $12 \mathrm{~h}$ treatments, respectively. The unknown genes and sequences are not shown in these tables.

A number of genes that are reported to be differentially expressed in defined immune responses were found to have increased expression after treatment with $[\mathrm{BF} /$ $\mathrm{S}+\mathrm{L} / \mathrm{Ep}$ ] [10]. These genes include angiomotin (Amot), chemokine (C-X-C motif) ligand 5 (Cxcl5), pro-platelet basic protein ( $\mathrm{Cxcl} 7$ ) and immunoresponsive gene 1 (Irg1) which were up-regulated at $4 \mathrm{~h}$ post-treatment with $[\mathrm{BF} / \mathrm{S}+\mathrm{L} / \mathrm{Ep}]$, and other genes including cytotoxic $\mathrm{T}$ lymphocyte-associated protein 4 (Ctla4) and chemokine (C-X-C motif) ligand 7 (Cxcl7) were strongly up-regulated at $12 \mathrm{~h}$ post-treatment. Among them, $\mathrm{Cxcl7}$ was upregulated at both $4 \mathrm{~h}$ and $12 \mathrm{~h}$ time points (Table 2 and 3 ). In addition, the expression of DC surface marker genes, such as $C d 40, C d 80, C d 86, M h c I I$ and $C d 11 c$, showed little or no changes after $[\mathrm{BF} / \mathrm{S}+\mathrm{L} / \mathrm{Ep}]$ treatment, confirming our previous flow cytometric analysis (Figure 1).

A number of the responsive genes found here have not previously been shown to be differentially expressed in DCs. Some of these include specific cell surface molecules related to cell adhesion or to regulation of cytoskeleton molecules, such as cadherin $10(\mathrm{Cdh} 10)$, cadherin 1 (Cdh1), integrin a6 (Itga6), neural cell adhesion molecule 2 (Ncam2), microtubule-associated protein 9 (Mtap9), Cd38, and gap junction protein alpha 1 (Gja1). RNA transcript levels for genes encoding several secreted 


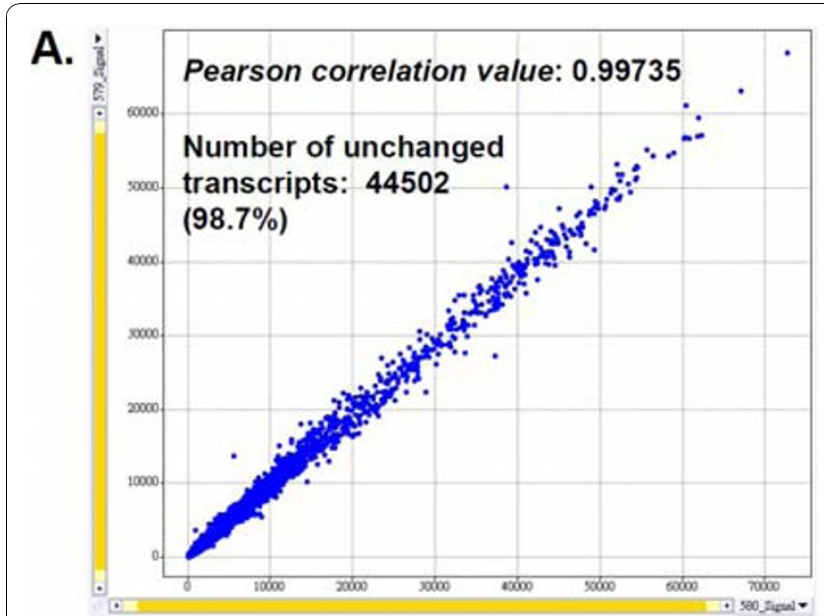

C.

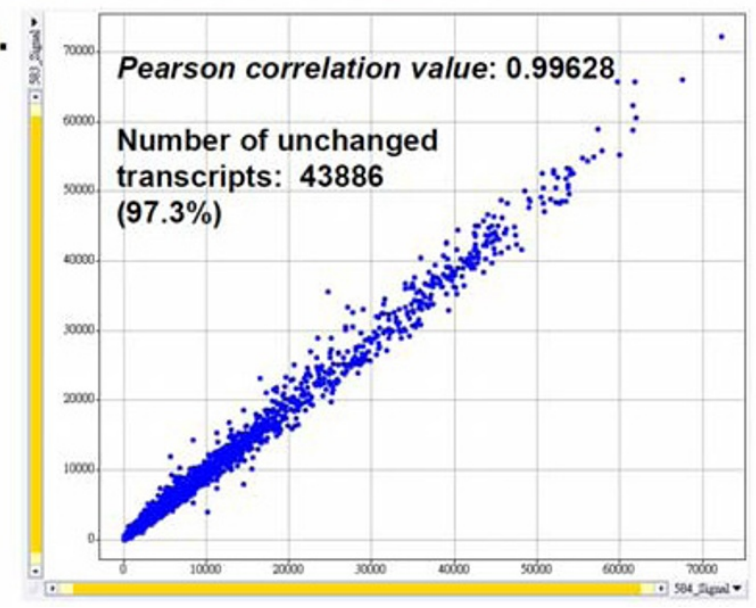

B.

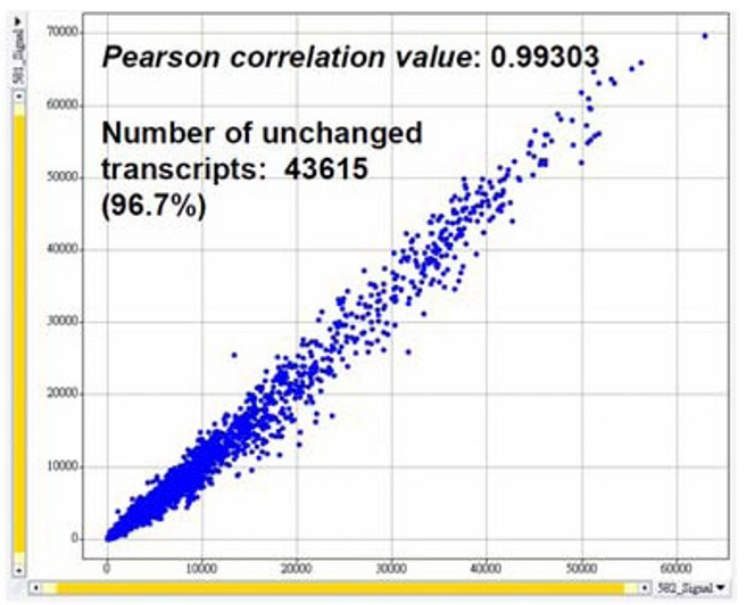

D.

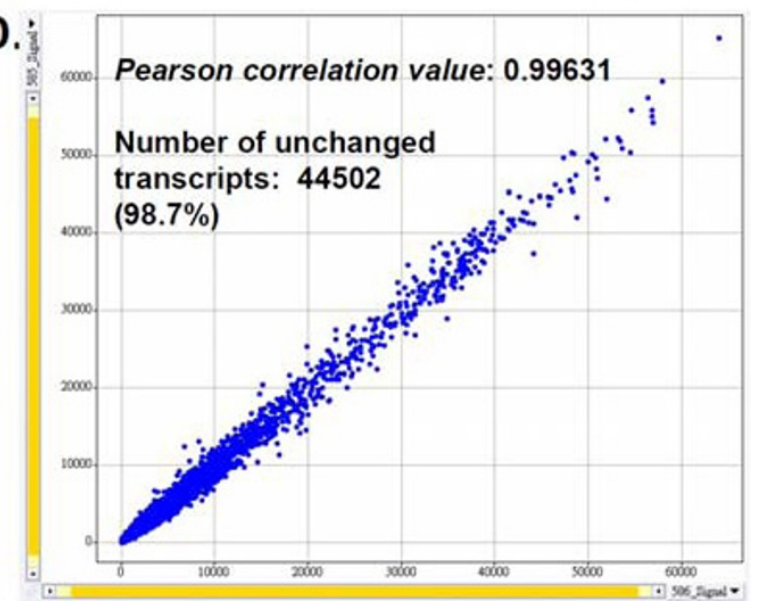

Figure 2 Correlation of biological sample replicates. A, DMSO (control) replicates (Affymetrix ID: 579, 580) after $4 \mathrm{~h}$ treatment. Pearson correlation value: 0.99735. B, [BF/S+L/Ep] replicates (Affymetrix ID: 581, 582) after $4 \mathrm{~h}$ treatment. Pearson correlation value: 0.99303. C, [DMSO] (control) replicates (Affymetrix ID: 583, 584) after $12 \mathrm{~h}$ treatment. Pearson correlation value: 0.99628 . D, [BF/S+L/Ep] replicates (Affymetrix ID: 585, 586) after $12 \mathrm{~h}$ treatment. Pearson correlation value: 0.99631. Data analysis used Spotfire software. Pearson correlation value and number of unchanged transcripts were calculated using GCOS software.

proteins were also increased by treatment with $[\mathrm{BF} / \mathrm{S}+\mathrm{L} /$ Ep]. These genes include chemokine (C-X-C motif) ligand 2 ( $\mathrm{Cxcl5}$ ), pro-platelet basic protein (chemokine (C-X-C motif) ligand 7) (Cxcl7), acid phosphatase (Acpp), chondroitin sulfate proteoglycan 2 (Cspg2), matrix metallopeptidase $8(\mathrm{Mmp} 8)$, and serpin peptidase inhibitor (Serpinb2). In comparison, the expression of transcripts encoding several enzymes fell after treatment with $[\mathrm{BF} /$ $\mathrm{S}+\mathrm{L} / \mathrm{Ep}]$. These genes included protein kinase C (Prkce), acyl-CoA synthetase (Acss 1$)$, ST8 alpha-N-acetylneuraminide alpha-2,8-sialyltransferase 6 (St8sia6), and Src-like-adaptor $(S l a)$. Moreover, the expression of mRNAs encoding transcription factors or DNA binding proteins localized in the nuclear compartment, such as ankyrin repeat and SOCS box-containing 2 (Asb2) and inhibitor of kappa light polypeptide gene enhancer in Bcells $(I k b k g)$, were increased in $[\mathrm{BF} / \mathrm{S}+\mathrm{L} / \mathrm{Ep}]$-treated DCs, and the expressions other transcription regulatory genes, such as synaptonemal complex protein 1 (Sycp1), RNA binding motif protein 14 (Rbm14), HECT domain containing 1 (Huwe1) and SRY (sex determining region Y)box 6 (Sox) were decreased (Table 2 and 3).

\section{Putative signaling networks involved in modulatory effect of $[B F / S+L / E p]$ on iBMDCs}

Functional genomics experimental approaches were employed in our previous study on the modulatory effect of Echinacea plant extracts on human DCs $[9,10]$. Using the same defined phytocompound extracts here we analyzed the genome-wide transcriptional response in the context of known functional activities and interrelationships among specific protein molecules and/or different cell phenotypes by using Ingenuity Systems, a structured network knowledge-based approach, to provide insight 
Table 1 Changes in gene expression in BMDCs in response to treatment with [BF/S+L/Ep]

\begin{tabular}{|c|c|c|c|c|c|}
\hline & $\begin{array}{c}\text { Expression change relative to } \\
\text { DMSO alone }\end{array}$ & $\begin{array}{c}\text { Up-regulated } \\
\text { genes }\end{array}$ & $\begin{array}{c}\text { Down-regulated } \\
\text { genes }\end{array}$ & $\begin{array}{c}\text { Total number of regulated } \\
\text { genes }\end{array}$ & $\begin{array}{l}\text { Percentage of all } \\
\text { genes (\%) }\end{array}$ \\
\hline \multicolumn{6}{|l|}{ At $4 \mathrm{h:}$} \\
\hline \multirow[t]{5}{*}{ Total genes } & Significant $^{a}$ & 513 & 472 & 985 & 2.90 \\
\hline & $\geq 1.5$ & 104 & 94 & 198 & 0.58 \\
\hline & $\geq 2^{\mathrm{b}}$ & 19 & 10 & 29 & 0.09 \\
\hline & $\geq 3$ & 6 & 5 & 11 & 0.03 \\
\hline & $\geq 4$ & 3 & 2 & 5 & 0.01 \\
\hline \multirow{5}{*}{$\begin{array}{l}\text { Immune- } \\
\text { related }\end{array}$} & Significant $^{a}$ & 89 & 83 & 172 & 0.51 \\
\hline & $\geq 1.5$ & 16 & 14 & 30 & 0.09 \\
\hline & $\geq 2^{c}$ & 4 & 0 & 4 & 0.01 \\
\hline & $\geq 3$ & 2 & 0 & 2 & 0.01 \\
\hline & $\geq 4$ & 0 & 0 & 0 & 0 \\
\hline $\begin{array}{l}\text { Non- } \\
\text { immune- } \\
\text { related }\end{array}$ & $\geq 2^{b-c}$ & 15 & 10 & 25 & 0.07 \\
\hline \multicolumn{6}{|l|}{ At $12 \mathrm{~h}:$} \\
\hline \multirow[t]{5}{*}{ Total Genes } & Significant ${ }^{a}$ & 605 & 736 & 1341 & 3.94 \\
\hline & $\geq 1.5$ & 128 & 132 & 260 & 0.76 \\
\hline & $\geq 2^{d}$ & 21 & 18 & 39 & 0.11 \\
\hline & $\geq 3$ & 6 & 5 & 11 & 0.03 \\
\hline & $\geq 4$ & 3 & 3 & 6 & 0.02 \\
\hline \multirow{5}{*}{$\begin{array}{l}\text { Immune- } \\
\text { related }\end{array}$} & Significant $^{a}$ & 144 & 120 & 264 & 0.78 \\
\hline & $\geq 1.5$ & 27 & 19 & 46 & 0.14 \\
\hline & $\geq 2^{e}$ & 2 & 0 & 2 & 0.01 \\
\hline & $\geq 3$ & 1 & 0 & 1 & 0 \\
\hline & $\geq 4$ & 1 & 0 & 1 & 0 \\
\hline $\begin{array}{l}\text { Non- } \\
\text { immune- } \\
\text { related }\end{array}$ & $\geq 2^{\text {d-e }}$ & 19 & 18 & 37 & 0.11 \\
\hline
\end{tabular}

into the regulation of BMDC activities that are relevant to the body immune system. Figure 3A shows the hypothetical or candidate networks revealed by clustering analysis of representative genes involved in the BMDC response to $[\mathrm{BF} / \mathrm{S}+\mathrm{L} / \mathrm{Ep}]$ treatment. Apparent temporal controls for coordination of specific gene expressions were classified into three different functional groups: the immune response related genes (Group 1); adhesion molecules, cytoskeleton and cell movement-related genes (Group 2); and the cell cycle, cell proliferation, and apoptosis-related genes (Group 3). These responses to treatment with $[\mathrm{BF} / \mathrm{S}+\mathrm{L} / \mathrm{Ep}]$ extract in iBMDCs may be viewed as an integrated cell-wide response involving cell trafficking, attachment, immunity and apoptosis.
To identify possible signal transduction pathways in response to $[\mathrm{BF} / \mathrm{S}+\mathrm{L} / \mathrm{Ep}]$ treatment, we analyzed, for both the $4 \mathrm{~h}$ and $12 \mathrm{~h}$ treatments, the $37 \mathrm{up}$-regulated genes using TRANSPATH software in the manner previously reported $[9,10]$. Signal transduction pathways involving the CRBP1, AhR, APC and Cyr61 genes with a $\geq 2$-fold change in expression level (Table 2) were predicted. Apparent signaling network and functional genomic analyses suggest that treatment of DCs with $[\mathrm{BF} /$ $\mathrm{S}+\mathrm{L} / \mathrm{Ep}$ ] may activate the JNK, PP2C- $\alpha$, AKT, ERK1/2 or MAPKAPK pathways, because expression of their downstream genes were up-regulated (Figure 3B). For those down-regulated genes, the TRANSPATH software was not able to predict a matched upstream pathway. 
Table 2 Up-regulation of genes in iBMDCs treated with [BF/S+L/Ep] for (A) $4 \mathrm{~h}$ or (B) $12 \mathrm{~h}$ compared to DMSO alone

\begin{tabular}{|c|c|c|c|}
\hline & Gene Name & Accession Number & Expression Ratio $^{\mathrm{a}}(+) /(-)$ \\
\hline \multicolumn{4}{|l|}{ At $4 \mathrm{h:}$} \\
\hline Cluster 1 & Adhesion molecules, Cytoskeleton, Cell movement & & \\
\hline Ncam2 & neural cell adhesion molecule 2 & NM_010954 & 6.57 \\
\hline Serpinb2 & serine (or cysteine) peptidase inhibitor, clade B, member 2 & NM_011111 & 4.50 \\
\hline Ikbkg & inhibitor of kappa B kinase gamma & NM_010547 & 2.03 \\
\hline Cluster 2 & Immune response & & \\
\hline Amot & angiomotin & NM_153319 & 2.48 \\
\hline $\mathrm{CxCl} 5$ & chemokine (C-X-C motif) ligand 5 & NM_009141 & 8.63 \\
\hline $\operatorname{lrg} 1$ & immunoresponsive gene 1 & XM_127883 & 2.17 \\
\hline $\mathrm{CxCl} 7$ & chemokine (C-X-C motif) ligand 7 & NM_023785 & 2.08 \\
\hline Cluster 3 & Signal transmission, Transporter & & \\
\hline Nrxn1 & neurexin I & Q9CS84 & 9.62 \\
\hline Sorbs1 & sorbin and $\mathrm{SH} 3$ domain containing 1 & NM_009166 & 3.70 \\
\hline Ahrr & aryl-hydrocarbon receptor repressor & NM_009644 & 2.37 \\
\hline Abce1 & ATP-binding cassette, sub-family E (OABP), member 1 & NM_015751 & 2.10 \\
\hline Cluster 4 & Cell cycle, DNA repair, Apoptosis & & \\
\hline Cyr61 & cysteine rich protein 61 & NM_010516 & 6.60 \\
\hline Mtap9 & microtubule-associated protein 9 & Q3TRRO & 2.64 \\
\hline Cluster 5 & Enzyme, Kinase & & \\
\hline Ppfia1 & protein tyrosine phosphatase, receptor type, $\mathrm{f}$ polypeptide (PTPRF) & XM_133979 & 2.74 \\
\hline Cluster 6 & DNA binding protein, Transcription factor & & \\
\hline Wdhd1 & WD-repeat HMG-box DNA binding protein 1 & NM_172598 & 2.04 \\
\hline Cluster 7 & Miscellaneous & & \\
\hline Prdm10 & PR domain containing 10 & Q3UTQ7 & 6.98 \\
\hline Tdrd3 & Tudor domain containing 3 & NM_172605 & 3.48 \\
\hline Mif4gd & MIF4G domain containing & NM_027162 & 2.16 \\
\hline Dnahc2 & dynein, axonemal, heavy chain 2 & О08826 & 2.09 \\
\hline
\end{tabular}

At $12 \mathrm{~h}$ :

Cluster 1 Adhesion molecules, Cytoskeleton, Cell movement

Serpinb2 serine (or cysteine) peptidase inhibitor, clade B, member 2

NM_011111 3.34

Cspg2 chondroitin sulfate proteoglycan 2

NM_019389 2.20

Mmp8 matrix metallopeptidase 8

NM_008611 2.18

Myo1d Myosin ID

NM_177390 2.07

Cluster 2 Signal transmission, Transporter

Phip pleckstrin homology domain interacting protein

Q32NY1 3.28

Cd38 CD38 antigen

NM_007646 2.51

Rbp1 retinol binding protein 1, cellular

NM_011254 2.28

Ap3s2 adaptor-related protein complex 3, sigma 2 subunit

NM_009682 2.12

Golph4 golgi phosphoprotein 4

NM_175193 2.03

Cluster $3 \quad$ Enzyme, Kinase

Dnm1l dynamin 1-like

NM_152816 13.11

Wdfy3 WD repeat and FYVE domain containing 3

NM_172882 4.64

Acpp acid phosphatase, prostate

NM_019807 2.18 
Table 2: Up-regulation of genes in iBMDCs treated with [BF/S+L/Ep] for (A) $4 \mathrm{~h}$ or (B) $12 \mathrm{~h}$ compared to DMSO alone (Continued)

\begin{tabular}{llll}
$\begin{array}{l}\text { Apc } \\
\text { Adhfe1 }\end{array}$ & $\begin{array}{l}\text { adenomatosis polyposis coli } \\
\text { alcohol dehydrogenase, iron containing, 1 }\end{array}$ & NM_007462 & 2.15 \\
Cluster $\mathbf{4}$ & NM_175236 & & 2.04 \\
Ctla4 & $\begin{array}{l}\text { Immune response } \\
\text { Cytotoxic T-lymphocyte-associated protein 4 } \\
\text { chemokine (C-X-C motif) ligand 7 }\end{array}$ & NM_009843 & 11.16 \\
Cluster $\mathbf{5}$ & RNA binding protein, Translation factor & NM_023785 & 2.77 \\
Mrps5 & mitochondrial ribosomal protein S5 & & 2.20 \\
Sf4 & splicing factor 4 & NM_029963 & 2.45 \\
Cluster $\mathbf{6}$ & DNA binding protein, Transcription factor & NM_027481 & \\
Asb2 & ankyrin repeat and SOCS box-containing protein 2 & & 2.75 \\
Cluster 7 & Miscellaneous & NM_023049 & \\
Dnahc2 & dynein, axonemal, heavy chain 2 & & 3.11 \\
Ccdc89 & coiled-coil domain containing 89 & O08826 & 2.01 \\
\hline Expression ratio is defined as relative difference in expression with (+) compared to without (-) treatment with [BF/S+L/Ep] plant extract: (-) is DMSO vehicle
\end{tabular}
control.

Table 3 Down-regulation of genes in iBMDCs treated with [BF/S+L/Ep] for (A) $4 \mathrm{~h}$ or (B) $12 \mathrm{~h}$ compared to DMSO alone

\begin{tabular}{|c|c|c|c|}
\hline & Gene Title & Accession Number & Expression Ratio $^{\mathrm{a}}(+) /(-)$ \\
\hline \multicolumn{4}{|l|}{ At $4 \mathrm{h:}$} \\
\hline Cluster 1 & Adhesion molecules, Cytoskeleton, Cell movement & & \\
\hline Cnn3 & calponin 3, acidic & NM_028044 & 0.13 \\
\hline Cdh10 & cadherin 10 & Q3UUB3 & 0.27 \\
\hline Itga6 & Integrin alpha 6 & NM_008397 & 0.50 \\
\hline Cluster 2 & Cell cycle, DNA repair, Apoptosis & & \\
\hline Sycp1 & synaptonemal complex protein 1 & NM_011516 & 0.25 \\
\hline Cluster 3 & Enzyme, Kinase & & \\
\hline Atad1 & ATPase family, AAA domain containing 1 & NM_026487 & 0.48 \\
\hline St8sia6 & $\begin{array}{l}\text { ST8 alpha-N-acetyl-neuraminide alpha-2,8- } \\
\text { sialyltransferase } 6\end{array}$ & NM_145838 & 0.45 \\
\hline Prkce & Protein kinase $C$, epsilon & NM_011104 & 0.47 \\
\hline Cluster 4 & DNA binding protein, Transcription factor & & \\
\hline Shprh & SNF2 histone linker PHD RING helicase & NM_172937 & 0.27 \\
\hline Zfp39 & zinc finger protein 39 & NM_011758 & 0.31 \\
\hline Cluster 5 & Miscellaneous & & \\
\hline Cep110 & centrosomal protein 110 & XM_981952 & 0.46 \\
\hline
\end{tabular}

\section{At $12 \mathrm{~h}:$}

Cluster $1 \quad$ Adhesion molecules, cytoskeleton; cell movement

\begin{tabular}{|c|c|c|c|}
\hline Cdh1 & Cadherin 1 & NM_009864 & 0.30 \\
\hline Gja1 & gap junction membrane channel protein alpha 1 & NM_010288 & 0.48 \\
\hline
\end{tabular}

Cluster 2 Signal transmission, Transporter

Rab17 RAB17, member RAS oncogene family 
Table 3: Down-regulation of genes in iBMDCs treated with [BF/S+L/Ep] for (A) $4 \mathrm{~h}$ or (B) $12 \mathrm{~h}$ compared to DMSO alone (Continued)

\begin{tabular}{|c|c|c|c|}
\hline Oscar & osteoclast associated receptor & NM_175632 & 0.44 \\
\hline Kcne3 & Voltage-gated potassium channel, Isk-related subfamily, gene 3 & NM_020574 & 0.49 \\
\hline Sla & src-like adaptor & NM_009192 & 0.50 \\
\hline Cluster 3 & Enzyme, Kinase & & \\
\hline Setd4 & SET domain containing 4 & NM_145482 & 0.32 \\
\hline Ndufb2 & NADH dehydrogenase (ubiquinone) 1 beta subcomplex, 2 & NM_026612 & 0.39 \\
\hline Acss1 & acyl-CoA synthetase short-chain family member 1 & NM_080575 & 0.40 \\
\hline Cluster 4 & DNA binding protein, Transcription factor & & \\
\hline Sox6 & SRY-box containing gene 6 & NM_011445 & 0.06 \\
\hline Dmc1h & disrupted meiotic cDNA 1 homolog & NM_010059 & 0.17 \\
\hline Nfxl1 & nuclear transcription factor, $X$-box binding-like 1 & Q3ULV1 & 0.36 \\
\hline Huwe1 & HECT, UBA and WWE domain containing 1 & NM_021523 & 0.41 \\
\hline Cluster 5 & Protein metastasis & & \\
\hline Fbxo36 & F-box only protein 36 & NM_025386 & 0.46 \\
\hline Cluster 6 & RNA binding protein, Translation factor & & \\
\hline Rbm14 & RNA binding motif protein 14 & NM_019869 & 0.50 \\
\hline Cluster 7 & Miscellaneous & & \\
\hline Speer4b & spermatogenesis associated glutamate (E)-rich protein $4 \mathrm{~b}$ & NM_028561 & 0.19 \\
\hline Ccdc21 & coiled-coil domain containing 21 & NM_144527 & 0.47 \\
\hline Mgl1 & macrophage galactose $\mathrm{N}$-acetyl-galactosamine specific lectin 1 & NM_010796 & 0.48 \\
\hline
\end{tabular}

Expression ratio is defined as relative difference in expression with (+) compared to without (-) treatment with [BF/S+L/Ep] plant extract; (-) is DMSO vehicle control.

\section{Identification of differentially expressed known or novel proteins in $B M D C s$ that respond to $[B F / S+L / E p]$}

Using 2D gel electrophoresis, we were able to routinely obtain representative, high resolution, and highly reproducible 2D protein profiles of mouse DCs as putative proteomic maps (data not shown). Treatment of DCs with $[\mathrm{BF} / \mathrm{S}+\mathrm{L} / \mathrm{Ep}]$ at $75 \mu \mathrm{g} / \mathrm{mL}$ resulted in significant changes in expression of some proteins in comparison to the solvent-treated mouse DC samples. Differentiallyexpressed proteins were then identified by MALDITOF-MS and in some cases subsequently analyzed with tandem MS/MS, after manual excision of these protein spots from gels. A total of 23 different known protein species were isolated and characterized by analysis with MALDI-TOF-MS peptide mass fingerprinting (PMF). Table 4 lists the changes in protein expression in DCs treated with $[\mathrm{BF} / \mathrm{S}+\mathrm{L} / \mathrm{Ep}]$ in vitro for $12 \mathrm{~h}$, as compared to solvent (vehicle) treatment (0.1\% DMSO). Expression of metabolism, cytoskeleton or NF- $\kappa \mathrm{B}$-signaling related proteins were most affected by $[\mathrm{BF} / \mathrm{S}+\mathrm{L} / \mathrm{Ep}]$. 2D gel electrophoretic analyses showed increased levels of a group of specific proteins, such as annexin A4 and peroxiredoxin (Figure 4A). In contrast, the levels of some other proteins, such as macrophage capping protein, were reduced (Figure 4B). These proteins, which function in cytoskeleton organization, did not show a detectable change in mRNA levels after $[\mathrm{BF} / \mathrm{S}+\mathrm{L} / \mathrm{Ep}]$ treatment.

\section{Effect of $[B F / S+L / E p]$ extract on BMDC trafficking}

The effect of $[\mathrm{BF} / \mathrm{S}+\mathrm{L} / \mathrm{Ep}]$ on $\mathrm{DC}$ mobility was evaluated by an in vivo DC trafficking assay. Primary BMDCs generated by in vitro culture were treated with $0.1 \%$ DMSO, $[\mathrm{BF} / \mathrm{S}+\mathrm{L} / \mathrm{Ep}]$ or LPS separately. Cells were then stained with fluorescein isothiocyanate isomer I (a green fluorescence dye) and administered to test mice via i.v. injection. After $24 \mathrm{~h}$, mice were sacrificed and DC motilities in vivo were compared by scoring the presence and number of DCs with green fluorescence dye in tissue sections of inguinal lymph node, spleen and liver. As seen in Figure 5, DCs treated with $[\mathrm{BF} / \mathrm{S}+\mathrm{L} / \mathrm{Ep}]$ showed a higher capacity to target lymph nodes and spleen (Figure 5-d, e) than DMSO-treated DCs (Figure $5 \mathrm{a}, \mathrm{b}$; Figure 6). In comparison, DCs stimulated by LPS showed a relatively higher capacity to target these immune tissues, particularly the spleen (Figure 5-g, h). 


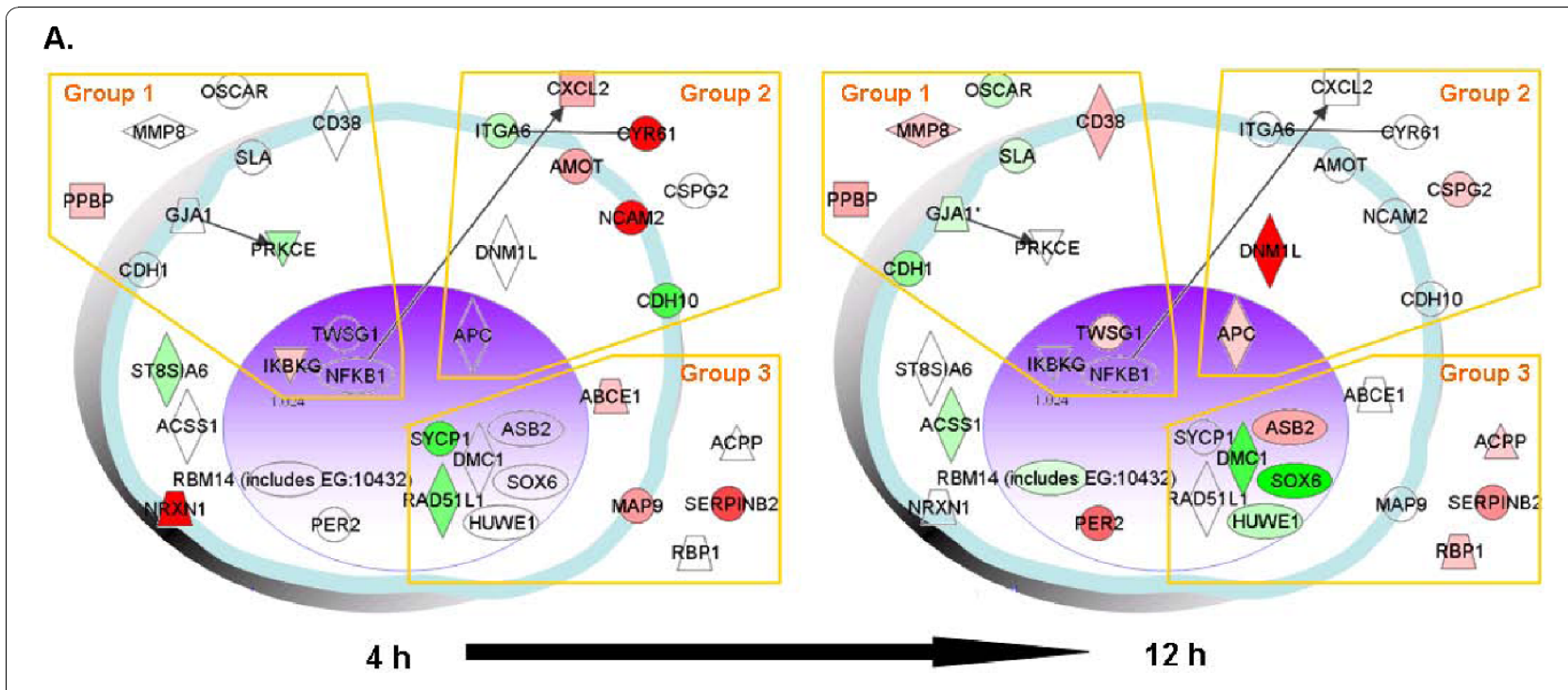

B.

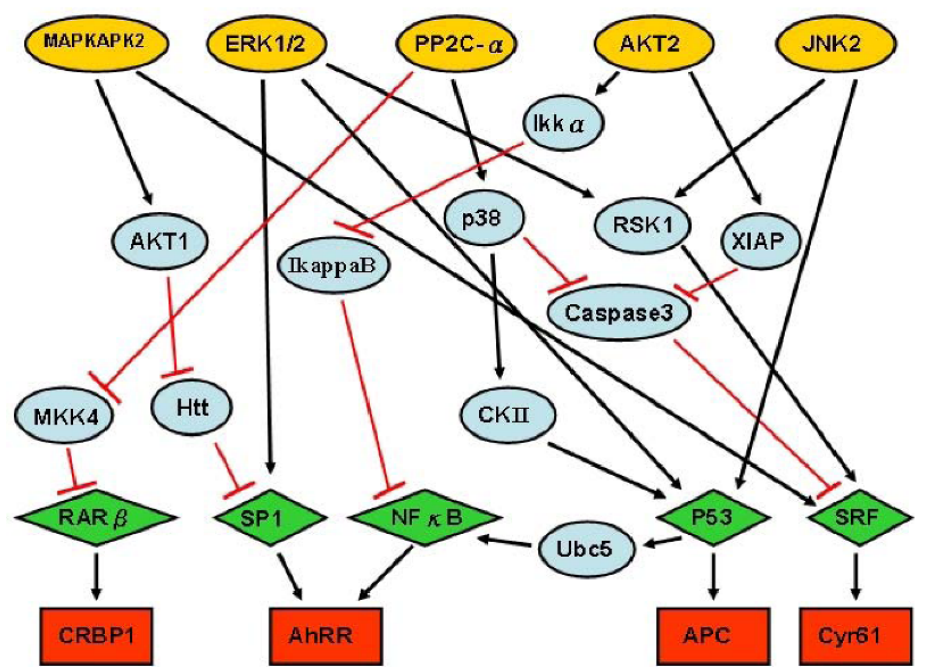

Figure 3 Pathway analysis of representative genes that responded to [BF/S+L/Ep] treatment. A prototypical cell was constructed from 37 representative genes that responded to treatment with $[\mathrm{BF} / \mathrm{S}+\mathrm{L} / \mathrm{Ep}]$ in vitro from $4 \mathrm{~h}$ to $12 \mathrm{~h}$. $\mathbf{A}$, Genes whose expression was up-regulated (more than doubled) are colored red, and those whose expression was down-regulated (to less than half) are shown in green. Selected regions of the network highlight several groups of genes. Group 1, Immune response related genes. Group 2, Adhesion molecules and cytoskeleton; cell movement related genes. Group 3, Cell cycle, cell proliferation and apoptosis related genes. Gene networks were analyzed with the Ingenuity Pathways program. B, The TRANSPATH Professional 7.1 database was searched to assess possible signaling pathways, networks or potential interactions among the responsive genes/target molecules in DCs treated with [BF/S+L/Ep]. The 37 genes that were up- or down-regulated at least 2-fold compared to controls were analyzed. Specifically, connections (hits) within 7 genes were employed as the parameter for the current search. Five postulated key molecules/pathways; JNK2 (c-Jun NH $\mathrm{N}_{2}$-terminal kinase 2), PP2C- $\alpha$ (protein phosphatase 2C-alpha), AKT (protein kinase B), ERK (extracellular signal-related kinase) and MAPKAPK (MAPK-activated protein kinase 2 ) that may be activated by [BF/S+L/Ep] treatment are predicted with arrows. The green rhombuses indicate the upstream transcription factors of responsive genes.

Tissues from liver of all test mice remained negative for trafficking of DCs throughout the tested experimental period (Figure 5-c, f, i and 5l). These data indicate that the Echinacea extract can stimulate enhanced migration and mobility of DCs in vivo, in addition to its specific effect on the transcriptome seen in vitro.
As shown in the insets of $d$ and e in Figure 5, for [BF/ $\mathrm{S}+\mathrm{L} / \mathrm{Ep}$ ]-treated DCs, the individual cellular events of DC migration, are seen mainly as separated, single unit fluorescent dots in the photomicrographs of test tissues, and the fluorescence intensities are, in general, medium to low. In contrast, the cellular behavior and light 
Table 4 Differentially expressed proteins identified by MALDI-TOF-MS/MS analysis of 2D gel protein profiles of

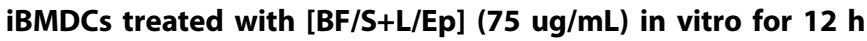

\begin{tabular}{|c|c|c|c|c|}
\hline $\begin{array}{l}\text { Spot } \\
\text { Number }\end{array}$ & Protein Name & $\begin{array}{l}\text { Relative } \\
\text { Protein Level }^{\mathrm{a}}\end{array}$ & $\begin{array}{l}\text { SwissProt } \\
\text { Accession Number }\end{array}$ & Biological Function \\
\hline 54 & Annexin A4 & 1.73 & P97429 & Signal transduction; cell communication \\
\hline 34 & Peroxiredoxin 4 & 1.56 & 008807 & Metabolism; Energy pathways \\
\hline 82 & Vimentin & 1.13 & P20152 & Cell growth/maintenance \\
\hline 26 & Alpha-actin-2 & 1.12 & P62739 & Cell growth/maintenance \\
\hline 23 & Proliferin-1 & 1.1 & P04095 & Cell growth/maintenance \\
\hline 98 & APAF1-interacting protein & 1.09 & Q9WVQ5 & apoptosis \\
\hline 1 & beta-actin & 1.05 & P99041 & Cell growth/maintenance \\
\hline 58 & Alpha-tubulin 1, 2, 4, 6 & 1.04 & P68369... & Cell growth/maintenance \\
\hline 79 & Heat shock cognate $71 \mathrm{kDa}$ protein & 1.04 & P63017 & Protein metabolism \\
\hline 109 & Solute carrier family 35 member E1 & 1.04 & Q8CD26 & Transport \\
\hline 55 & Actin, cytoplasmic 1 (Beta-actin) & 1.03 & P60710 & Cell growth/maintenance \\
\hline 88 & YEATS domain-containing protein 4 & 0.96 & Q9CR11 & $\begin{array}{l}\text { Regulation of nucleobase, nucleoside, nucleotide and } \\
\text { nucleic acid metabolism }\end{array}$ \\
\hline 6 & Phenylalanyl-tRNA synthetase & 0.92 & Q99M01 & Protein metabolism \\
\hline 41 & $\begin{array}{l}\text { Protein disulfide-isomerase A3 } \\
\text { [Precursor] }\end{array}$ & 0.92 & P27773 & Protein metabolism \\
\hline 38 & Phosphoglycerate mutase 1 & 0.87 & Q9DBJ1 & Metabolism; Energy pathways \\
\hline 78 & Heat shock protein 9, [Precursor] & 0.84 & P38647 & Protein metabolism \\
\hline 56 & F-actin capping protein alpha subunit & 0.83 & P47754 & Cell growth/maintenance \\
\hline 13 & Cathepsin S & 0.81 & 070370 & Protein metabolism \\
\hline 91 & Nucleoside diphosphate kinase & 0.74 & Q9WV84 & Metabolism; Energy pathways \\
\hline 70 & Alpha-enolase & 0.73 & P17182 & Metabolism; Energy pathways \\
\hline 45 & Macrophage capping protein & 0.63 & P24452 & Cell growth/maintenance \\
\hline 192 & $\begin{array}{l}\text { Voltage-gated potassium channel } \\
\text { subfamily KQT member } 2\end{array}$ & 0.46 & Q97351 & Transport \\
\hline 191 & $\begin{array}{l}\text { Protein tyrosine phosphatase } \\
\text { mitochondrial } 1\end{array}$ & 0.34 & Q66GT5 & signal transduction; cell communication \\
\hline
\end{tabular}

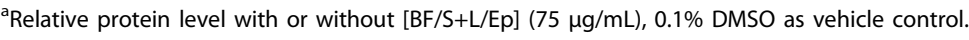

intensities of the fluorescent test DCs in LPS-treated samples (Figure 5-g and $5 \mathrm{~h}$ ) are more aggregated and clumped together. In addition the colors are considerably brighter than those seen for the [BF/S+L/Ep]-treated DCs. It was also observed that under in vitro test conditions, the individual DCs treated with LPS became enlarged in size, and thus could apparently absorb higher levels of FITC-labeled dextran and also already tended to aggregate together, as compared to DCs treated with $[\mathrm{BF} / \mathrm{S}+\mathrm{L} / \mathrm{Ep}]$. These effects of LPS may also contribute to the observed results seen in trafficking experiments, where more aggregated and brighter DCs were detected in targeted tissues in LPS-treated DCs than in cells treated with $[\mathrm{BF} / \mathrm{S}+\mathrm{L} / \mathrm{Ep}]$.

The potential effect of $[\mathrm{BF} / \mathrm{S}+\mathrm{L} / \mathrm{Ep}]$ on key cellular physiological functions of DCs was further investigated in an in vitro study, where the expression of specific chemotaxis-related receptors for trafficking of DCs was analyzed by flow cytometry. BMDCs with or without LPS stimulation were treated with $[\mathrm{BF} / \mathrm{S}+\mathrm{L} / \mathrm{Ep}]$ for $24 \mathrm{~h}$ and then assayed for expression of the three cell surface markers CCR4, CCR5 and CCR7 (Figure 6), which are known to play an important role in the mobility of DCs, are expressed on DCs at distinguishable differentiation stages, and are located at specific sites in different tissues [23]. Here, CCR $4^{+} \mathrm{CCR} 5^{+}$and $\mathrm{CCR} 4^{+} \mathrm{CCR} 7^{+}$dendritic cells were considered as immature and mature DC populations, respectively, as observed during their in vivo maturation processes. Our data show that in vitro treatment of DCs with $[\mathrm{BF} / \mathrm{S}+\mathrm{L} / \mathrm{Ep}]$ significantly increases the expression level of CCR 5 on immature DCs (Figure 6 but does not affect CCR5 expression on LPS-induced mature DCs. Furthermore, we have observed that our herbal extract treatment caused a suppressive effect on the "endogenous" or "non-LPS-induced" generation of mature DCs from immature DCs, as assessed by the CCR7 activity measured for DMSO-treated and [BF/S+L/ Ep]-treated DCs (Figure 6). Considering our prior results obtained both in vitro (i.e., DC maturation, Figure 1) and in vivo (i.e., DC trafficking capacity, Figure 5), the data shown in Figure 6 thus confirm our current key finding that the $[\mathrm{BF} / \mathrm{S}+\mathrm{L} / \mathrm{Ep}]$-enhanced $\mathrm{DC}$ trafficking ability 


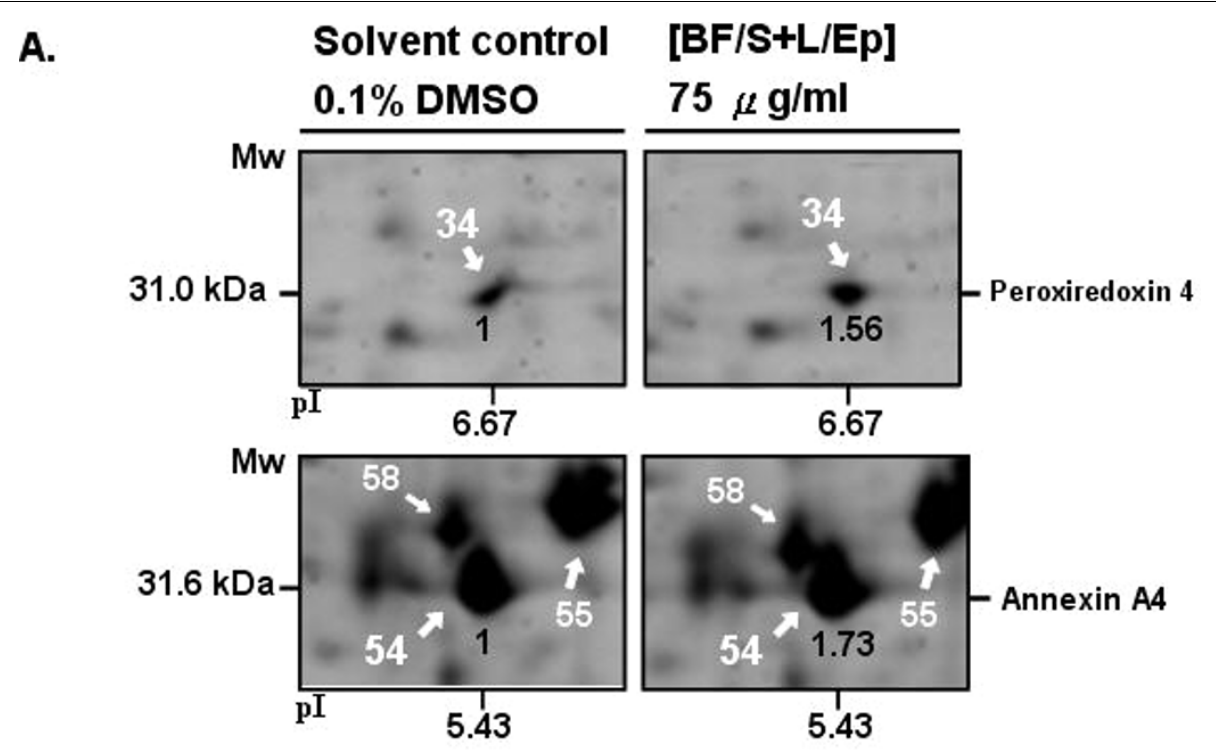

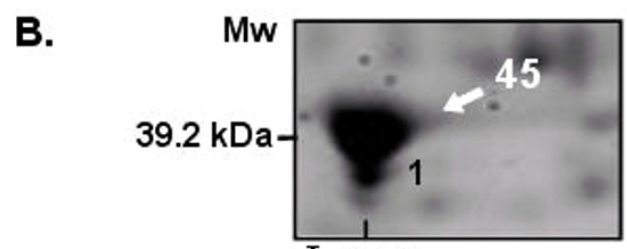

pI 6.73

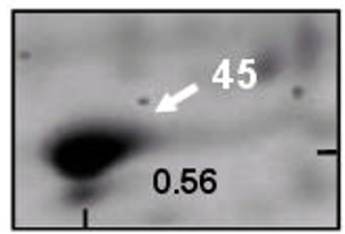

6.73
Macrophage capping protein

Figure 4 Proteomics analyses of $E$. purpurea phytocompound effects on mouse bone-marrow derived immature dendritic cells (iBMDCs). Effect of Echinacea purpurea extract on differential protein expression in iBMDCs was evaluated by 2D gel electrophoretic analysis. 500 $\mu \mathrm{g}$ of total cell proteins from various treatments of iBMDCs were applied to PH 5-8 IPG strips. After isofocusing and 2D gel separation, SYPRO Ruby was used to stain proteins. Images on gel were analyzed using PD-Quest software. Forty-two differentially-expressed proteins were trypsindigested in situ, and 23 protein spots were identified by MALDI-TOF MS, with their locations in gel assigned a number. These protein ID numbers are listed in Table 4. A, Up-regulated and B, down-regulated protein spots are reported on a representative two-dimensional gel corresponding to protein expression profile of iBMDCs. The expression ratios are shown in bold print. Gels shown here are representative of thee independent experiments.

appears to be readily distinguishable from the LPSinduced DC mobility.

\section{Discussion}

By using a combination of genomic and proteomic experimental approaches, we investigated the ex vivo effects of a candidate medicinal plant extract, $[\mathrm{BF} / \mathrm{S}+\mathrm{L} /$ $E p]$, on the differentiation and modulation activities of mouse BMDCs. This study extends our previous report $[9,10]$, where human DCs were used in a similar functional genomics study. In addition to the ex vivo test system, this study also examined the in vivo effect of $[\mathrm{BF} / \mathrm{S}+\mathrm{L} / \mathrm{Ep}]$ in experimental mice. Together, our current and previous findings on both human and mouse DCs, under in vitro as well as in vivo conditions, have provided us with a comprehensive information base for future translational research into potential clinical application of $[\mathrm{BF} / \mathrm{S}+\mathrm{L} / \mathrm{Ep}]$ as botanical drugs or nutritional supplements. As demonstrated in Fig 2, our DNA microarray test systems and the experimental cell culture replicate samples were highly reproducible and consistent. We identified that close to $0.36 \%$ of the genes from the BMDC genome are significantly affected by treatment with $[B F / S+L / E p]$. These differentially expressed and responsive genes were mostly related to cell adhesion and motility, immune response, signaling molecules and specialty enzymes. Some of these genes have been previously reported to be related to functions of DCs, but a large portion are reported here for the first time.

In this study, flow cytometry analysis on a number of CD markers showed that expression of several mouse DC surface markers was not significantly affected by treatment with $[\mathrm{BF} / \mathrm{S}+\mathrm{L} / \mathrm{Ep}]$, this finding was not consistent with our previous data for human DCs [10]. This result may suggest that specific biochemical and cellular effects of herbal extract on DC maturation may vary considerably between different mammalian species, 


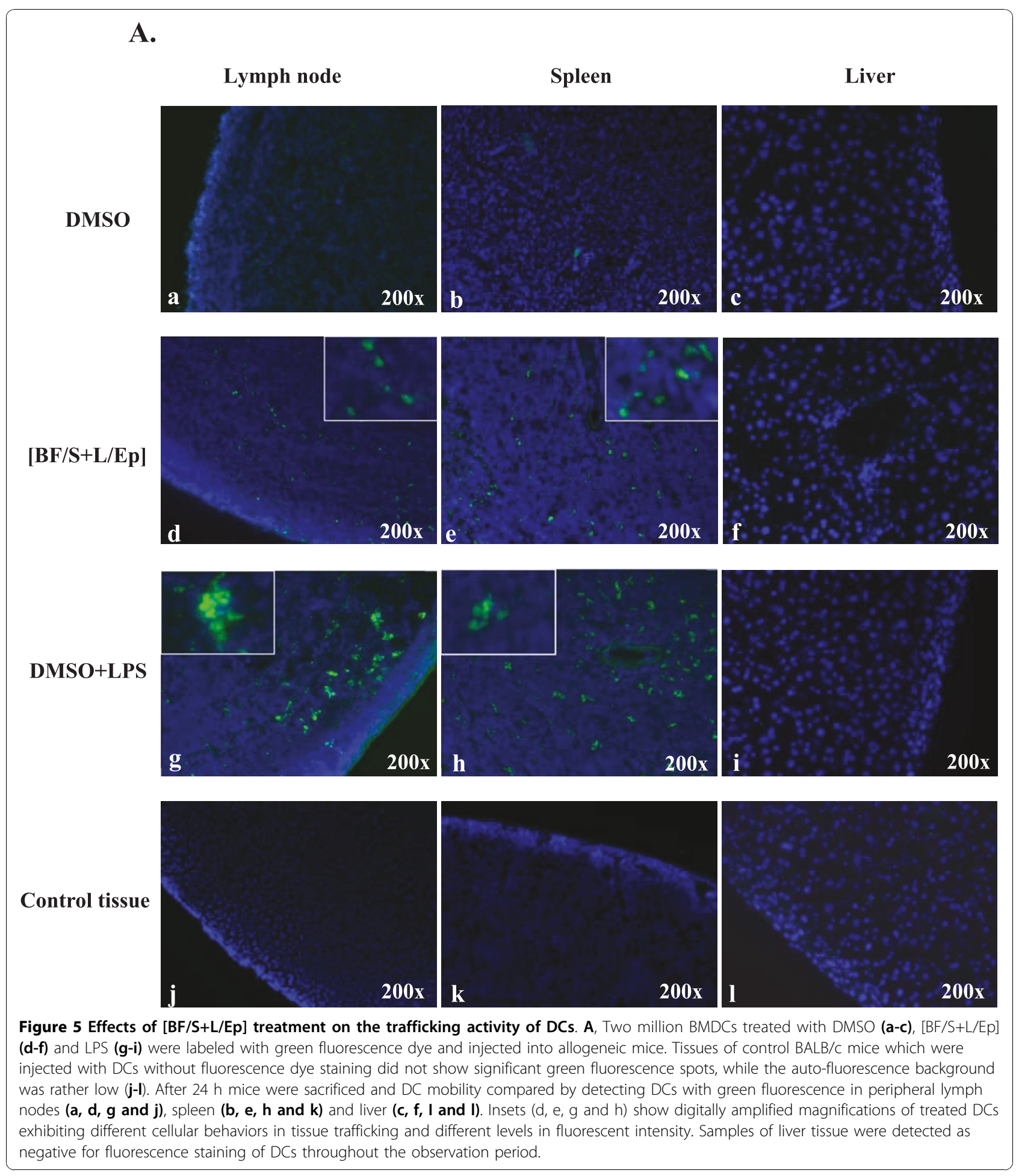

implying that future translation of experimental findings or results from animal models into human application need to be carefully addressed and considered with multiple references.

Immature DCs migrate from the blood to other tissues where they take up and process target antigens.
Such DCs then subsequently migrate to the draining lymphoid tissues, resulting in the priming of naïve $\mathrm{T}$ cells following antigen presentation. During their migration, DCs are known to be involved in several adhesion or cognition events. For instance, E-cadherin, which is uniquely expressed by Langerhans DCs (LCs), permits 


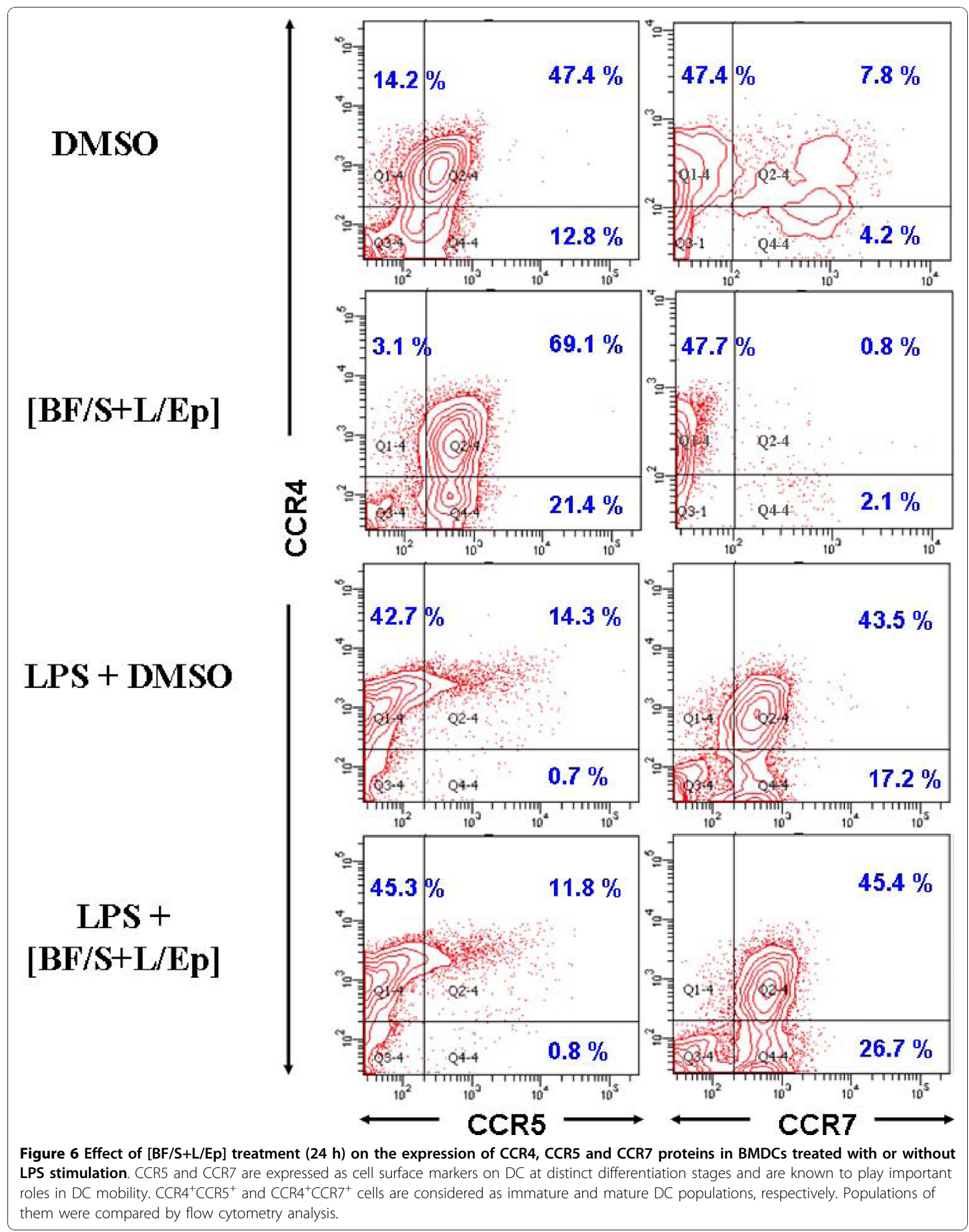


the residence of LCs in the epidermis [24]. Such antigen encounter can result in down-regulation of E-cadherin that allows LC migration out of the skin [25]. The release of collagenase by DCs can facilitate their migration through the basement membranes [26]. Our data show that the gene expressing E-cadherin was downregulated in DCs at both $4 \mathrm{~h}$ and $12 \mathrm{~h}$ after treatment with $[\mathrm{BF} / \mathrm{S}+\mathrm{L} / \mathrm{Ep}]$. Genes encoding for the cell adhesion protein integrin alpha 6 (Itga6) and the cell signaling protein gap junction membrane channel protein $\alpha 1$ (Gja1) were down-regulated at $4 \mathrm{~h}$ and $12 \mathrm{~h}$ post treatment, respectively. Moreover, expression of specific collagenases and proteases, such as $M m p-8$ (Table 2), $M m p-2$, and $M m p-14$, and the macrophage elastase Mmp-12 (data not shown in Table 2 and 3, due to relatively low level slightly lower than 2 fold in fold change) were appearently up-regulated after $12 \mathrm{~h}$ of treatment. Taking these results together, and in conjunction with the in vivo trafficking assay data (Figure 5), we suggest that $[\mathrm{BF} / \mathrm{S}+\mathrm{L} / \mathrm{Ep}]$ phytoextract can confer a modulatory effect on cell mobility of mouse BMDCs. In future studies it will be important and interesting to determine whether such an in vivo effect is also observed for human DCs, and thus for potential clinical application.

In general, various major inflammatory and immunomodulatory cytokines such as IL- 1 , TNF- $\alpha$, IFN $\gamma$, IL-4, IL-5, IL-6, IL-13, and IL-17, which are readily induced by injury or infection, are known to stimulate the production of a spectrum of different chemokines though mediation via their respective receptors [27-29]. For instance, it is known that mice deficient in CCR2, the only known CCL2 receptor, have impaired $\mathrm{Th}_{1}$ responses [30], owing to a reduction of monocyte trafficking to the sites of inflammation [31]. In this study we show that a number of immune-related genes were up-regulated after $4 \mathrm{~h}$ and $12 \mathrm{~h}$ treatment of $[\mathrm{BF} / \mathrm{S}+\mathrm{L} / \mathrm{Ep}]$. These include genes encoding angiomotin (Amot), which is involved in cell movement and embryogenesis [32], chemokine (C-X-C motif) ligand 2 ( $\mathrm{Cxcl5}$ ), pro-platelet basic protein $(\mathrm{Cxcl} 7)$, involved in chemokine activity and leukocyte transendothelial migration [33], immunoresponsive gene 1 (Irg1) and cytotoxic T-lymphocyte-associated protein 4 (Ctla4). These results suggest that $[\mathrm{BF} / \mathrm{S}+\mathrm{L} / \mathrm{Ep}]$ may modify the chemotactic behavior of mouse DCs. Since some responsive chemokines such as CXCL5 and CXCL7, which we detected here in test DCs, are currently not well defined in terms of cellular function and biochemistry, further studies are needed to examine how $[\mathrm{BF} / \mathrm{S}+\mathrm{L} / \mathrm{Ep}]$ can exert an effect on the secretion of these chemokines and to find out whether these chemokines do play a role in the chemoattraction and trafficking of treated DCs in the mouse system. On the other hand, our in vitro study did allow us to show that phenotypic expression of chemotaxis-related receptor proteins, including CCR5 and
CCR7, can be significantly regulated in test mouse DCs treated with $[\mathrm{BF} / \mathrm{S}+\mathrm{L} / \mathrm{Ep}]$ (Figure 6$)$. Whether or not specific chemotaxis-related receptors, such as CCR5, can mechanistically modulate the $[\mathrm{BF} / \mathrm{S}+\mathrm{L} / \mathrm{Ep}]$-enhanced $\mathrm{DC}$ mobility will also require further investigations. Unlike our previous findings on human DCs [9], [BF/S+L/Ep] treatment had a readily distinguishable and a slower level effect on the expression of immune-related genes in mouse BMDCs. These results again suggest, like the effects observed for cell surface marker proteins, the immunomodulatory effects of phytocompounds from Echinacea extracts apparently could also differ substantially between humans and mice.

It is well known that DCs are the principal antigen presenting cells (APCs) for T-cell priming [34]. It is important to note, however, that DCs are also involved in the induction of central and peripheral tolerance [35]. One protein, called cytotoxic $\mathrm{T}$ lymphocyte-associated antigen 4 (CTLA-4), is known as an immunomodulatory membrane molecule. By decreasing $\mathrm{T}$-cell responsiveness and raising the threshold for $\mathrm{T}$-cell activation, CTLA-4 plays a critical role in the maintenance of peripheral T-cell tolerance [36,37]. Here, we found that the expression of Ctla4 was drastically up-regulated in DCs after $12 \mathrm{~h}$ of treatment with [BF/S+L/Ep]. Whether the CTLA-4 signaling system for DCs were also affected by our test phyto-compound and could in turn further affect $\mathrm{T}$ cell or other DC associated immunities would need to be further analyzed in future studies.

In human DCs, we showed that $[\mathrm{BF} / \mathrm{S}+\mathrm{L} / \mathrm{Ep}]$ can effect the expression of specific cytoskeleton proteins, including macrophage-capping protein, cofilin, profilin, F-actin capping protein $\beta$ subunit, and laminin $A / C$ [10]. In the present study using mouse DC cells, our 2D gel electrophoretic analyses on DC proteins revealed that expression of several cytoskeleton-related proteins, such as alphaactin-2 and F-actin capping protein alpha and macrophage capping protein, were also altered by $[\mathrm{BF} / \mathrm{S}+\mathrm{L} / \mathrm{Ep}]$. These results together suggest that Ep phytocompound extract modulates specific cytoskeleton functions, which are known to play a role in testing DCs to specific immune processes. A group of specific proteins, such as annexin A4, which can reversibly modify various membrane properties (e.g., fluidity and permeability), anchoring of cytoskeletal elements, aggregation of vesicles, and the regulation of ion conductance [38], and peroxiredoxin 4, which exhibits thioredoxin-dependent peroxidase activity and regulates the activation of the transcription factor NF$\kappa \mathrm{B}$ [39], were up-regulated in mouse DCs after treatment with $[\mathrm{BF} / \mathrm{S}+\mathrm{L} / \mathrm{Ep}]$ (Figure $4 \mathrm{~B})$. These results suggest again that $[\mathrm{BF} / \mathrm{S}+\mathrm{L} / \mathrm{Ep}]$ may affect the cell mobility and NF- $\kappa \mathrm{B}$ signaling of BMDCs. Moreover, expression of several cellular metabolism-related proteins, including vimentin, proliferin-1 precursor-1, $-2,-3$, phenylalanyl-tRNA synthetase, 
phosphoglycerate mutase 1 , cathepsin S, nucleoside diphosphate kinase and alpha-enolase were also affecteded by $[\mathrm{BF} / \mathrm{S}+\mathrm{L} / \mathrm{Ep}]$ treatment (Table 4). Whether these changes are functionally related to specific cellular and molecular activities of mouse DCs needs to be further investigated.

Previous studies have demonstrated that specific alkylamides of $E$. purpurea can effectively stimulate macrophage function in healthy rats or RAW 264.7 cells $[40,41]$. In addition, specific in vitro effects of Echinacea extract and several of its phytochemical components on NF- $\kappa \mathrm{B}$ expression in Jurkat cells (a human T-cell line) have been reported [42]. Recently we reported that phytocompounds from E. purpurea extracts could affect specific cell-surface marker expressions and cytoskeleton rearrangement in treated human DCs $[9,10]$. These findings suggest that a spectrum of specific immunomodulatory effects in DCs can be modulated by phytochemicals from E. purpurea at the cellular level. It is interesting to find that in this study, although the specific groups of responsive RNA transcripts and proteins seem to differ substantially from the results obtained from our previous studies on human DCs, the end result in terms of cellular functions seems to suggest that many of them, such as cytoskeleton-associated gene or protein expression can in fact be quite similar, and this provides valuable correlated information for future evaluations of the various molecular mechanisms of these effects. The in vivo DC trafficking results obtained in this study may further suggest the importance of the mobility and cytoskeletal components of the differentially expressed transcriptome for future evaluation of pharmaco-genomics activities in a mouse DC system in vivo. Besides, we believe that our current transient labeling system for DCs may provide future application to translational research on phytochemical or herbal medicinal effect on DCs.

\section{Conclusion}

In this study, data obtained from both in vitro transcriptomic analyses and in vivo DC trafficking assays suggested that $[\mathrm{BF} / \mathrm{S}+\mathrm{L} / \mathrm{Ep}]$ treatment can affect $\mathrm{DC}$ mobility. The effects of this bioactive herbal extract on expression of cytoskeleton-related RNA transcripts as well as on differential protein expressions related to cell adherence and other DC functions add complementary and supportive information to our previous studies on human DCs $[9,10]$. Taken together, our research shows that this candidate herbal medicine may cause drastic modulatory effects on specific immune cells (DCs) by regulating key cellular behaviors. In addition, bioinformatics studies from this and our previous study [10] have revealed a group of candidate target molecules and signaling networks, for example the JNK, PP2C- $\alpha$, AKT and MAPKAPK pathways, that we believe warrant future systematic studies as key targets for immunomodulatory phytomedicines, via mediation with dendritic cells.

\section{Methods}

Plant materials and plant extract preparations and fractionations

Echinacea purpurea plants grown to the flowering stages were harvested from a reputable organic farm in Puli, Nantou County, Taiwan as previously described [9]. Stem and leaf tissues of fresh plants were extracted at room temperature by imbibition in $70 \%$ aqueous ethanol for 35 days, mimicking a traditional Chinese medicine (TCM) preparation protocol. The final 70\% ethanolsoluble fraction was dried under vacuum, re-suspended and dissolved in 1 liter of water and then successively partitioned with ethyl acetate ( $1 \mathrm{~L} \times 3$ times) and $n$-butanol $(1 \mathrm{~L} \times 3$ times) to yield three subfractions designated as the $\mathrm{EA}, \mathrm{BuOH}$ and water $\left(\mathrm{H}_{2} \mathrm{O}\right)$ fractions of the $(\mathrm{S}+\mathrm{L})$ extract $[10,43]$. The percentage yield for the $\mathrm{BuOH}$ fraction of the stem and leaf tissue extract $[\mathrm{BF} / \mathrm{S}+\mathrm{L} / \mathrm{Ep}]$ was $7.23 \%$ of the $70 \%$ ethanol extracts by dry weight.

\section{Culture of DCs from bone marrow}

DCs were generated by using the method described by Inaba et al. [44]. Six-week-old female BALB/c (H-2Kd, I-Ad) mice were purchased from the National Laboratory Animal Center and kept under specific pathogen free (SPF) conditions. Femurs and tibiae were removed after euthanasia and the bone marrow was flushed with RPMI-1640 medium using a syringe with a $0.45-\mathrm{mm}$ needle. Red blood cells in suspension were lysed with ACK lysing buffer $\left(150 \mathrm{mM} \mathrm{NH}{ }_{4} \mathrm{Cl}, 1.0 \mathrm{mM} \mathrm{KHCO} 3\right.$, $0.1 \mathrm{mM}$ EDTA) for $5 \mathrm{~min}$. Bone marrow cells were suspended at concentration of $1 \times 10^{7}$ cells $/ 30 \mathrm{ml}$ complete media (CM, RPMI-1640 supplemented with 10\% fetal bovine serum (FBS), $2 \mathrm{mM}$ L-glutamine, $1 \%$ of nonessential amino acids and $100 \mathrm{U} / \mathrm{mL}$ penicillin and 100 $\mu \mathrm{g} / \mathrm{mL}$ streptomycin). Test cells were cultured for up to 9 days with $1000 \mathrm{U} / \mathrm{mL}$ of $\mathrm{GM}-\mathrm{CSF}$ at $37^{\circ} \mathrm{C}, 5 \% \mathrm{CO}_{2}$. On day 3 , two-thirds of the medium was removed and $30 \mathrm{~mL}$ fresh medium with GM-CSF was added to the cells. On day 6 , culture plates were gently swirled and the floating and loosely adherent cells were discarded. Aliquots of $75 \%$ of culture media were replaced with fresh culture medium with GM-CSF. On day 9, nonadherent cells were collected and used as the immature DC population for subsequent tests and analyses.

\section{Treatment of DCs with E. purpurea extract}

$[\mathrm{BF} / \mathrm{S}+\mathrm{L} / \mathrm{Ep}]$ was dissolved in $100 \%$ pure and endotoxinfree dimethyl sulfoxide (DMSO). The working concentrations of each extract sample were prepared by serial dilutions to $75 \mu \mathrm{g} / \mathrm{mL}$. This dosage for stimulation of DCs was chosen based on our results obtained by MTT 
assay: treatment of test cells with $[\mathrm{BF} / \mathrm{S}+\mathrm{L} / \mathrm{Ep}]$ at 0,25 , $50,75,100,500 \mu \mathrm{g} / \mathrm{ml}$ resulted in a cell viability, on average, of $100 \%, 102 \%, 107 \%, 104 \%, 99 \%$ and $73 \%$, respectively, as compared to the vehicle control (data not shown). Treatment at $100 \mu \mathrm{g} / \mathrm{ml}[\mathrm{BF} / \mathrm{S}+\mathrm{L} / \mathrm{Ep}] \mathrm{might}$ cause some limited cytotoxicity, whereas the dosage of $75 \mu \mathrm{g} / \mathrm{ml}$ does not result in any cytotoxic effects. The final DMSO concentration reached $0.1 \%$ in each DC culture. An aliquot of a $0.1 \%$ DMSO solution in medium only was thus used as a vehicle (negative) control. LPS from Escherichia coli (serotype 055:B5) was purchased from Sigma (St. Louis, MO) and used for cell activation or quality control at $1 \mu \mathrm{g} / \mathrm{mL}$.

\section{Flow cytometric analysis}

All cell samples were stained using a direct immunofluorescence staining method. For each step of the staining, $2 \times 10^{5}$ cells were treated with specific antibodies for $30 \mathrm{~min}$ at $4{ }^{\circ} \mathrm{C}$ in $45 \mu \mathrm{L}$ of phosphate-buffered saline (PBS) containing $2 \%$ bovine serum albumin (BSA). Test cells of each experimental group were first incubated with purified anti-CD16/CD32 antibody (mouse IgG2a, 93) for 10 minutes on ice. Fluorescein isothiocyanate (FITC)- or phycoerythin (PE)-labeled monoclonal antibodies were then used for staining of MHC class II (I-Ab, mouse IgG2a, 2G9), CCR4 (mouse IgG, 2G12), CCR5 (mouse IgG, HM-CCR5), CCR7 (mouse IgG2a, 4B12), CD40 (mouse IgG, HM40-3), CD80 (mouse IgM, 16-10A1), CD86 (mouse IgG, GL-1) and CD11c (mouse IgG, N418) on test cells. All antibodies were purchased from Biolegend (San Diego, CA). After cell samples were incubated with test antibody at $4^{\circ} \mathrm{C}$ for $40 \mathrm{~min}$, cells were washed twice with PBS and fixed with $1 \%$ paraformaldehyde. Test cells were then analyzed in a Coulter EPICS XL flow cytometer (Beckman/Coulter).

\section{DNA microarray analysis for gene expression}

Total RNA was isolated using TRIzol (Invitrogen) according to the manufacturer's instruction and used to generate cRNA targets. A total of $7 \mu \mathrm{g}$ of RNA from each sample was used to synthesize the first strand cDNA using $\mathrm{T}_{7}$-Oligo $(\mathrm{dT})$ primer and T7 RNA polymerase by in vitro transcription (IVT) reaction. The biotinylated cRNA products were then cleaned up according to the Affymetrix protocol. An aliquot of $15 \mu \mathrm{g}$ of RNA per sample was then hybridized to a Affymetrix gene chip, the mouse Genome 4302.0 array, containing 45,101 probesets and variants from over 34,000 well-characterized mouse genes, using a standard protocol suggested by the Affymetrix menu. Images of the array signals were collected on Affymetrix scanners. A total of 8 hybridizations were performed for immature DCs, while each time point and treatment was analyzed in duplicates on separate chips. Standard Pearson correlation coefficients were used to determine the consistency of gene expression in each replicate Affymetrix array.

$$
\text { Pearson correlation value }=\frac{\sum(x-\bar{x})(y-\bar{y})}{\sqrt{\sum(x-\bar{x})^{2} \sum(y-\bar{y})^{2}}}
$$

Data was analyzed using Spotfire software, which includes algorithms that determine whether a gene is absent or present and whether the expression level of a gene in an experimental sample is significantly increased or decreased relative to a control sample. Changes in expression levels are presented as averages of $\log _{2}$ (BF/ $\mathrm{S}+\mathrm{L} /$ Ep treatment)/(DMSO treatment). The microarray data have been deposited to the Gene Expression Omnibus database at NCBI (GEO; http://www.ncbi.nlm.nih. gov/projects/geo/) under the accession number GSE19369.

\section{2-D gel electrophoresis and image analysis}

Total cellular proteins of immature dendritic cells were prepared using $0.3 \mathrm{~mL}$ of sample buffer [7 M urea (Bio-Rad), 2 M thiourea, 4\% CHAPS (Sigma), 10\% 1,4dithioerythitol (Merck, Frankfurt, Germany), 2\% Phamalyte 3-10] by vortexing for $1 \mathrm{~h}$ and then collecting the protein supernatants by 55,000 RPM and for $1 \mathrm{~h}$. Protein concentration was determined by using a protein assay kit (Bio-Rad, Hercules, CA). 2-D gel electrophoresis was carried out using the Bio-Rad Protean IEF cell and Protean electrophoresis cell system as described previously $[10,45]$ with modifications. Digitalized gel images were analyzed with 2-D analysis software (PD Quest, Bio-Rad) as previously described [10]. The image with the highest number of spots was selected as the master gel. Automatically detected images of protein spots in test gels were then manually edited to include the low intensity spots and correct for spot artifacts. For the match set containing images with $\mathrm{pI} 5-8$, the spot volume (intensity integrated over the spot area) was normalized by the volume of total spots in the gel. The data was then exported to Microsoft Excel.

\section{Protein identification by MALDI-TOF-MS}

Protein identification was performed as described previously [10]. Briefly, each gel slice was cut into small pieces with a scalpel. Reduction was achieved with 10 $\mathrm{mM}$ DTT at $57^{\circ} \mathrm{C}$ for $1 \mathrm{~h}$. Alkylation reaction was performed with $55 \mathrm{mM}$ iodoacetamide for $1 \mathrm{~h}$ at room temperature in the dark. Gel spots were then washed for $10 \mathrm{~min}$ alternately with $25 \mathrm{mM} \mathrm{NH}_{4} \mathrm{HCO}_{3}$ and acetonitrile. Gel pieces were completely dried using a Speed Vac. The dried gel pieces were then immersed in three volumes of trypsin solution (V5111; Promega, Madison, WI), at $20 \mathrm{ng} / \mathrm{mL}$ in $25 \mathrm{mM} \mathrm{NH}_{4} \mathrm{HCO}_{3}$ (freshly diluted). 
In-gel digestion was performed at $37^{\circ} \mathrm{C}$ overnight. The tryptic peptides were extracted from test gel pieces in 5 $\mathrm{mL}$ of $70 \%$ acetonitrile $5 \% \mathrm{HCOOH}$ by sonication. The supernatant was dried under a Speed Vac and $6 \mu \mathrm{L}$ of $1 \% \mathrm{HCOOH}$ was then added to each test sample. Protein identification using MALDI-Q-TOF-MS analysis was performed by the Proteomics Core Facility of the Institute of Biological Chemistry, Academia Sinica, Taiwan [10]. The MS data with monoisotopic peptide masses were searched against the NCBI protein database using the MASCOT search engine (Matrix Science, London, UK).

\section{DC trafficking in vivo}

To analyze the migration of ex-vivo cultured DCs under in vivo experimental conditions in test mice, $1 \times 10^{6}$ cultured DCs were labeled with fluorescein isothiocyanate isomer I (See Figure 5; green fluorescence dye) at $300 \mu \mathrm{g} / \mathrm{mL}$ at $37^{\circ} \mathrm{C}$ for $20 \mathrm{~min}$, cells were then washed three times with PBS and subsequently injected into the tail vein of syngeneic BALB/c mice. Fresh lymph node (LN), spleen and liver tissues were harvested and frozen tissue sections of $12 \mu \mathrm{m}$ in thickness were mounted on precleaned microscope slides (Superfrost/Plus; Fisher Scientific, Pittsburgh, PA), and stored at $-80^{\circ} \mathrm{C}$. To retain the fluorescent signal, the tissue sections were pretreated with $4 \%$ paraformaldehyde at room temperature. Tissue sections were first incubated with blocking solution (2\% fetal calf serum in PBS) for $10 \mathrm{~min}$. Nuclear staining was then performed with 4,6-diamidino-2-phenylindole (DAPI) and followed by washing with $1 \times \mathrm{PBS}(2 \times 5 \mathrm{~min}$ each). Tissue sections were then mounted with $50 \%$ glycerol in $\mathrm{H}_{2} \mathrm{O}$ with coverslips. Fluorescence microscopy evaluation of immunostained frozen sections was performed using a Zeiss Axiovert $200 \mathrm{M}$ microscope (Carl Zeiss, Heidelberg, Germany). Microscopy photos and images were captured with a digital camera (Orca ER; Hamamatsu) and processed using Axiovision 4.6.3 (Carl Zeiss). The number of individually florescent spot as test cells was then scored for comparative analysis and the data was exported to Microsoft Excel.

\section{Pathway analysis of representative genes involved in/ associated with effects of [BF/S+L/Ep] on BMDCs}

Using a Web-based entry tool developed by Ingenuity Systems [46], findings presented in peer-reviewed scientific publications were systematically encoded into ontology by content and modeling experts. A molecular network of direct physical, transcriptional and enzymatic interactions was observed between mammalian orthologs. For a better understanding of the temporal response of gene expression in the immune system, we constructed a prototypical cell showing the possible candidate signaling pathways, containing 35 genes $(>2$-fold change) responding to treatment with $[\mathrm{BF} / \mathrm{S}+\mathrm{L} / \mathrm{Ep}]$. The candidate genes of interest also were keyed into TRANSPATH professional database, version 7.1, (Biobase Biological Databases $\mathrm{GmbH}$, Germany) to identify possible target molecules and signaling pathways, using four hierarchical levels of regulation $[9,10]$.

\section{Acknowledgements}

This work was supported by grants from the Genomic and Proteomic Program Academia Sinica (94F002-1), Taiwan, Republic of China. We thank Dr. Pei-Ing Huang, for her suggestions about the application of the bioinformatics software for cDNA microarray data, Ms. Ming-Yan Zhou for her technical assistance in performing cDNA microarray hybridized reaction, and Dr. Harry Wilson and Ms. Miranda Loney of Academia Sinica for professional editing of the manuscript.

\section{Author details}

'Agricultural Biotechnology Research Center, Academia Sinica, Taipei, Taiwan. ${ }^{2}$ Institute of Statistical Science, Academia Sinica, Taipei, Taiwan. ${ }^{3}$ Taiwan International Graduate Program (TIGP) - Molecular and Biological Agricultural Sciences Program, Academia Sinica, Taipei, Taiwan. ${ }^{4}$ Graduate Institute of Biotechnology, National Chung Hsing University, Taichung, Taiwan.

${ }^{5}$ Department of Mathematics, Tamkang University, Taipei County, Taiwan.

\section{Authors' contributions}

SYY served as the key experimenter and author of the draft manuscript. WHW and KA provided useful revision and reorganization of the manuscript. BXW helped the in vivo DC trafficking experiments. HMW helped and introduced bioinformatics analyses on DNA microarray data as a team. NSY is $\mathrm{Pl}$ and principal author of the manuscript. All authors read and approved the final manuscript

Received: 19 January 2010 Accepted: 1 November 2010

Published: 1 November 2010

\section{References}

1. Banchereau J, Briere F, Caux C, Davoust J, Lebecque S, Liu YJ, Pulendran B, Palucka K: Immunobiology of dendritic cells. Annu Rev Immunol 2002, 18:767-811.

2. Gary S: Overcoming Self: A company tries to turn the immune system against cancer. Scientific American 2004, 219:18-19.

3. Reinhard G, Marten A, Kiske SM, Feil F, Bieber T, Schmidt-Wolf IG: Generation of dendritic cell-based vaccines for cancer therapy. $\mathrm{Br} J$ Cancer 2002, 86(1):529-1533.

4. Dermime S, Armstrong A, Hawkins RE, Stern PL: Cancer vaccines and immunotherapy. Br Med Bull 2002, 62:149-162.

5. Celluzzi CM, Mayordomo JI, Storkus WJ, Lotze MT, Falo LD: Peptide-pulsed dendritic cells induce antigen-specific CTL-mediated protective tumor immunity. J Exp Med 1996, 183:283-7.

6. Miconnet I, Coste I, Beermann F, Haeuw JF, Cerottini JC, Bonnefoy JY, Romero P, Renno T: Cancer vaccine design: A novel bacterial adjuvant for peptide-specific CTL induction. J Immunol 2001, 166:4612-9.

7. Nestle FO, Aligagic S, Gilliet M, Sun Y, Grabbe S, Dummer R, Burg G, Schadendorf D: Vaccination of melanoma patients with peptide- or tumor lysate-pulsed dendritic cells. Murine dendritic cells pulsed with whole tumor lysates mediate potent antitumor immune responses in vitro and in vivo. Nat Med 1998, 4:328-32.

8. Palucka AK, Laupeze B, Aspord C, Saito H, Jego G, Fay J, Paczesny S, Pascual V, Banchereau J: Immunotherapy via dendritic cells. Adv Exp Med Biol 2005, 560:105-114.

9. Wang CY, Chiao MT, Yen PJ, Huang WC, Hou CC, Chien SC, Yeh KC, Yang WC, Shyur LF, Yang NS: Modulatory effects of Echinacea purpurea extracts on human dendritic cells: A cell- and gene-based study. Genomics 2006, 88:801-808.

10. Wang CY, Staniforth V, Chiao MT, Hou CC, Wu HM, Yeh KC, Chen CH, Hwang PI, Wen TN, Shyur LF, Yang NS: Genomics and proteomics of immune modulatory effects of a butanol fraction of echinacea purpurea in human dendritic cells. BMC Genomics 2008, 9(1):479. 
11. Canedy D: Real medicine or medicine show? Growth of herbal sales raises issues about value. New York Times 1998, 23:C1.

12. Ernst E: The risk-benefit profile of commonly used herbal therapies. In Ann Intern Med. Volume 136. Ginkgo:, St. John's Wort, Ginseng, Echinacea, Saw Palmetto, and Kava; 2002:42-53.

13. Barrett $B$, Kiefer D, Rabago D: Assessing the risks and benefits of herbal medicine: an overview of scientific evidence. Altern Ther Health Med 1999, 5:40-49.

14. Burger RA, Torres AR, Warren RP, Caldwell VD, Hughes BG: Echinaceainduced cytokine production by human macrophages. Int $J$ Immunopharmacol 1997, 19:371-379.

15. Rudolf $B$ : Chemical, analysis and immunological investigations of Echinacea phytopharmaceuticals. Immunomodulatory Agents from Plants 1999, 41-88.

16. Braunig $B$, Limburg $E$, Knick E: Enhancement of resistance in common cold by Echinacea purpurea. Z Phytother 1992, 13:7-13.

17. Bauer $V$, Jurcic $K$, Puhlmann J, Wagner $V$ : Immunologic in vivo and in vitro examinations of Echinacea extracts. Arzneim Forsch 1998, 38:276-281.

18. Roesler J, Emmendorffer A, Steinmuller C, Luettig B, Wagner H, LohmannMatthes ML: Application of purified polysaccharides from cell cultures of the plant Echinacea purpurea to test subjects mediates activation of the phagocyte system. Int J Immunopharmacol 1991, 13:931-941.

19. Schoop R, Klein P, Suter A, Johnston SL: Echinacea in the prevention of induced rhinovirus colds: a meta-analysis. Clin Ther 2006, 28:174-183.

20. Shah SA, Sander S, White CM, Rinaldi M, Coleman Cl: Evaluation of Echinacea for the prevention and treatment of the common cold: a meta-analysis. Lancet Infect Dis 2007, 7:473-480.

21. Lockhart DJ, Dong H, Byrne MC, Follettie MT, Gallo MV, Chee MS, Mittmann M, Wang C, Kobayashi M, Horton H, Brown EL: Expression monitoring by hybridization to high-density oligonucleotide arrays. Nat Biotechnol 1996, 14:1675-1680.

22. Pandey A, Mann M: Proteomics to study genes and genomes. Nature 2000, 405:837-846

23. Sozzani S, Allavena $P$, Vecchi A, Mantovani A: The role of chemokines in the regulation of dendritic cell trafficking. J Leukoc Biol 1999, 66(1):1-9.

24. Jakob T, Udey MC: Regulation of E-cadherin-mediated adhesion in Langerhans cell-like dendritic cells by inflammatory mediators that mobilize Langerhans cells in vivo. J Immunol 1998, 160:4067-73.

25. Tang A, Amagai M, Granger LG, Stanley JR, Udey MC: Adhesion of epidermal Langerhans cells to keratinocytes mediated by E-cadherin. Nature 1993, 361:82-85

26. Kobayashi Y: Langerhans' cells produce type IV collagenase (MMP-9) following epicutaneous stimulation with haptens. Immunology 1997, 90:496-501.

27. Baggiolini M, Dewald B, Moser B: Human Chemokines: an update. Annu Rev Immunol 1997, 15:675-705.

28. Rollins BJ: Chemokines. Blood 1997, 90:909-28.

29. Luster AD: Chemokines-chemotactic cytokines that mediate inflammation. N Engl J Med 1998, 338:436-45.

30. Boring L, Gosling J, Chensue SW, Kunkel SL, Farese RVJ: Impaired monocyte migration and reduced type 1 (Th1) cytokine responses in CC chemokine receptor 2 knockout mice. J Clin Invest 1997, 100:2552-61.

31. Peters W, Dupuis $M$, Charo IF: A mechanism for the impaired IFN-gamma production in C-C chemokine receptor 2 (CCR2) knockout mice: role of CCR2 in linking the innate and adaptive immune responses. J Immunol 2000, 165:7072-77.

32. Shimono A, Behringer RR: Angiomotin regulates visceral endoderm movements during mouse embryogenesis. Current Biology 2003, 13(7):613-7.

33. Carninci $P$, et al: The transcriptional landscape of the mammalian genome. Science 2006, 309(5740):1559-63.

34. Banchereau J, Steinman RM: Dendritic cells and the control of immunity. Nature 1998, 392:245-52

35. Brocker $\mathrm{T}$, Riedinger $\mathrm{M}$, Karjalainen $\mathrm{K}$ : Targeted expression of major histocompatibility complex (MHC) class II molecules demonstrates that dendritic cells can induce negative but not positive selection of thymocytes in vivo. J Exp Med 1997, 185:541-50.

36. Thompson CB, Allison JP: The emerging role of CTLA-4 as an immune attenuator. Immunity 1997, 7:445-450

37. Lee KM, Chuang E, Griffin M: Molecular basis of T cell inactivation by CTLA-4. Science 1998, 282:2263-2266.
38. Gerke V, Moss SE: Annexins: From Structure to Function. Physiol Rev 2002, 82:331-371.

39. Wong CM, Chun AC, Kok KH, Zhou Y, Fung PC, Kung HF, Jeang KT, Jin DY: Characterisation of human and mouse peroxiredoxin IV: evidence of inhibition by Prx-IV of epidermal growth factor- and p53-induced reactive oxygen species. Antioxid Redox Signal 2002, 2:507-518.

40. Goel V, Chang C, Slama JV, Barton R, Bauer R, Gahler R, Basu TK: Alkylamides of Echinacea purpurea stimulate alveolar macrophage function in normal rats. Int Immunopharmacol 2002, 2(2-3):381-7.

41. Zhai Z, Solco A, Wu L, Wurtele ES, Kohut ML, Murphy PA, Cunnick JE: Echinacea increases arginase activity and has anti-inflammatory properties in RAW 264.7 macrophage cells, indicative of alternative macrophage activation. J Ethnopharmacol 2009, 25; 122(1):76-85.

42. Matthias A, Banbury L, Bone KM, Leach DN, Lehmann RP: Echinacea alkylamides modulate induced immune responses in T-cells. Fitoterapia 2008, 79(1):53-8.

43. Wang SY, Kuo YH, Chang HN, Kang PL, Tsay HS, Lin KF, Yang NS, Shyur LF: Profiling and characterization of antioxidant activities in Anoectochilus formosanus Hayata. J Agric Food Chem 2002, 50:1859-1865.

44. Inaba K, Steinman RM, Pack MW, Aya H, Inaba M, Sudo T, Wolpe S, Schuler G: Identification of proliferating dendritic cell precursors in mouse blood. J Exp Med 1992, 176:1693-1702

45. Pereira SR, Faca VM, Gomes GG, Chammas R, Fontes AM, Covas DT, Greene LJ: Changes in the proteomic profile during differentiation and maturation of human monocyte-derived dendritic cells stimulated with granulocyte macrophage colony stimulating factor/interleukin- 4 and lipopolysaccharide. Proteomics 2005, 5:1186-1198.

46. Calvano SE, Xiao W, Richards DR, Felciano RM, Baker HV, Cho RJ, Chen RO, Brownstein BH, Cobb JP, Tschoeke SK, Miller-Graziano C, Moldawer LL, Mindrinos MN, Davis RW, Tompkins RG, Lowry SF: A network-based analysis of systemic inflammation in humans. Nature 2005, 13; 437(7061):1032-7.

doi:10.1186/1471-2164-11-612

Cite this article as: Yin et al:: Stimulatory effect of Echinacea purpurea extract on the trafficking activity of mouse dendritic cells: revealed by genomic and proteomic analyses. BMC Genomics 2010 11:612.

\section{Submit your next manuscript to BioMed Central and take full advantage of:}

- Convenient online submission

- Thorough peer review

- No space constraints or color figure charges

- Immediate publication on acceptance

- Inclusion in PubMed, CAS, Scopus and Google Scholar

- Research which is freely available for redistribution
C Biomed Central 